
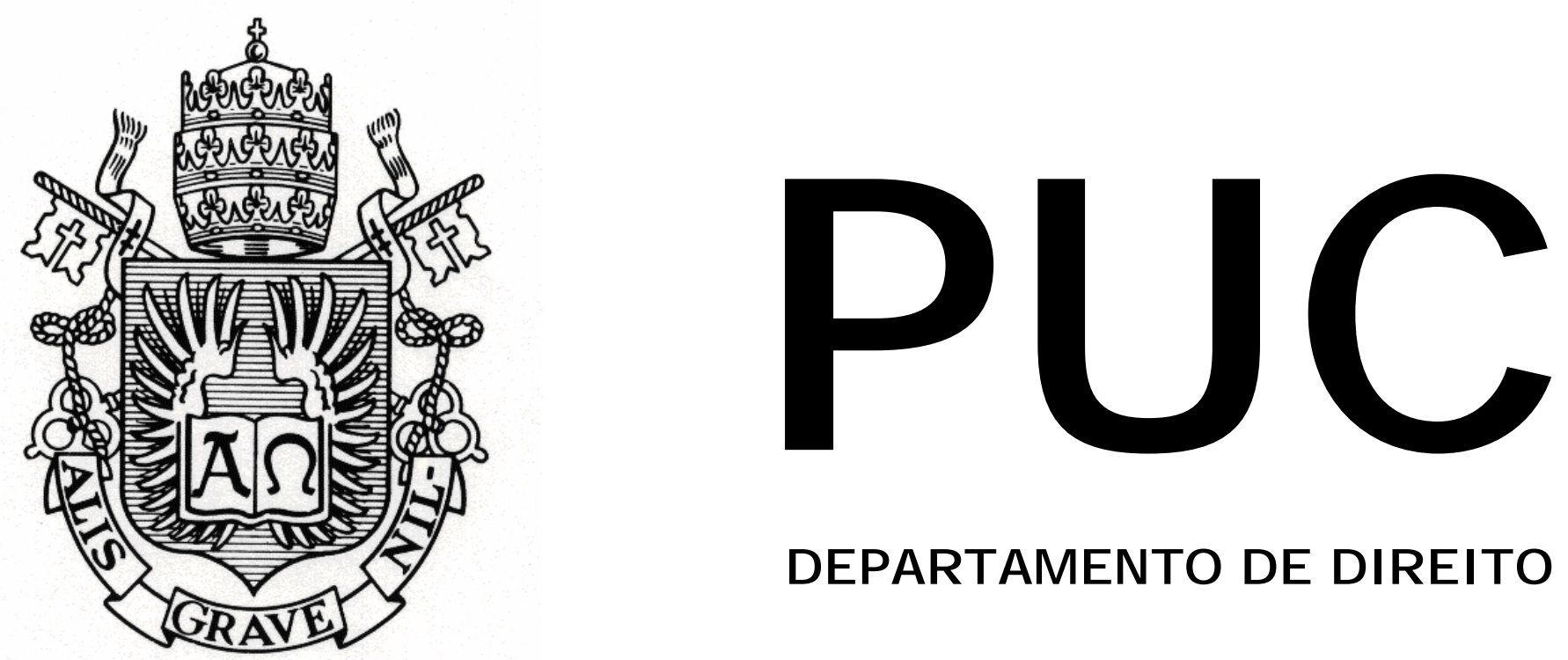

DEPARTAMENTO DE DIREITO

\title{
LIBERDADE RELIGIOSA E OS LIMITES DE INTERVENÇÃO DE UM ESTADO LAICO NO ÂMBITO DAS CONFISSÕES
}

por

PRISCILLA FERREIRA NOBRE ROCHA

ORIENTADOR: Fábio Carvalho Leite 2010.1

PONTIFÍCIA UNIVERSIDADE CATÓLICA DO RIO DE JANEIRO RUA MARQUÊS DE SÃO VICENTE, 225 - CEP 22453-900 RIO DE JANEIRO - BRASIL 


\title{
LIBERDADE RELIGIOSA E OS LIMITES DE INTERVENÇÃO DE UM ESTADO LAICO NO ÂMBITO DAS CONFISSÕES
}

\author{
por
}

\section{PRISCILLA FERREIRA NOBRE ROCHA}

Monografia apresentada ao Departamento de Direito da Pontifícia Universidade Católica do Rio de Janeiro (PUC-Rio) para a obtenção do Título de Bacharel em Direito.

Orientador: Fábio Carvalho Leite 


\section{RESUMO}

O presente trabalho visa abordar questões pertinentes à relação do Estado laico e as confissões religiosas, tendo em vista o tratamento superficial que a doutrina brasileira tem dado ao tema, principalmente ao relativo à intervenção do Estado no âmbito interno das entidades religiosas, ponto central desta monografia.

Deste modo, busca-se, aqui, chamar atenção para o direito à liberdade religiosa gozado não apenas pelos indivíduos, mas também pelas pessoas jurídicas, digam-se, confissões religiosas. Este assunto é praticamente esquecido pela doutrina, sendo analisado apenas os direitos das pessoas físicas e ignorando-se, de certa forma, ou apenas citando-se, os das pessoas jurídicas. Procura-se destacar, portanto, a importância de estudar esse assunto com o fim de evitar intervenções abusivas do Estado nas questões internas das religiões. Assim, questões que envolvem valores e doutrinas das confissões religiosas, incluindo-se doutrinas de cunho segregacionista, formas de professar o credo, critérios de seleção de membros e líderes, decisões tomadas pelas entidades religiosas e sua repercussão, movimentos que tem buscado suprimir esse direito concedido às igrejas e demais entidades religiosas, serão discutidas nesta monografia, visando-se contribuir para o debate acerca desse tema que, até então, tem tido pouca abordagem.

Palavras-chave: Liberdade religiosa, confissões religiosas, Estado laico. 


\section{SUMÁRIO}

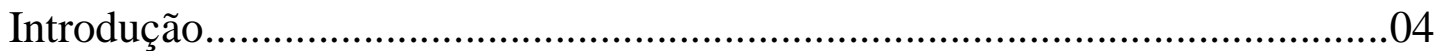

Capítulo I

Considerações preliminares acerca da liberdade religiosa

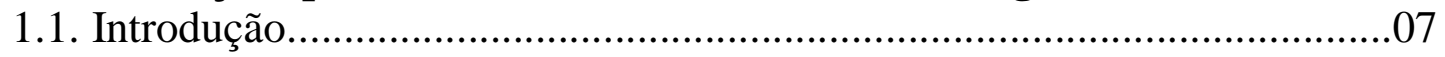

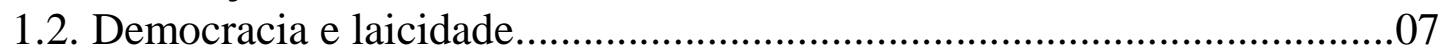

1.3. Dimensão jurídico-subjetiva da liberdade religiosa....................................14

1.3.1. Liberdade de crença e de culto.........................................................16

1.3.2. Liberdade de organização religiosa....................................................19

Capítulo II

A liberdade religiosa titulada pelas entidades religiosas

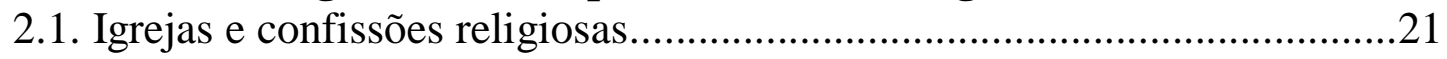

2.2. Direito geral de autodeterminação das confissões religiosas.......................27

2.2.1. Liberdade de auto-organização........................................................27

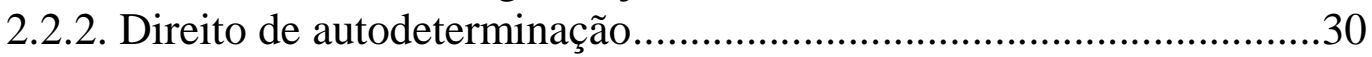

2.3. Funções próprias / fins religiosos das confissões religiosas.........................32

2.4. Invocação ao direito à liberdade religiosa por outras pessoas jurídicas......36

Capítulo III

A ingerência do Estado no seio das confissões religiosas

3.1. A vinculação das pessoas jurídicas pelo direito à liberdade religiosa........38

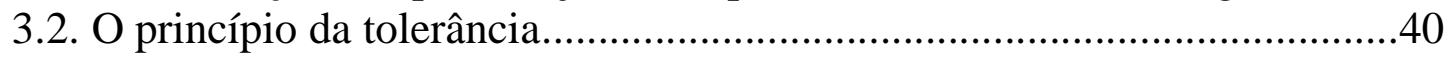

3.3. Direitos fundamentais e intervenção estatal..............................................42

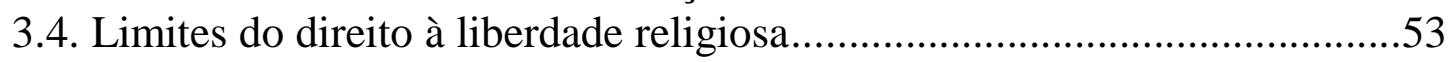

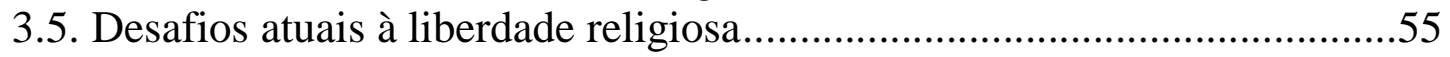

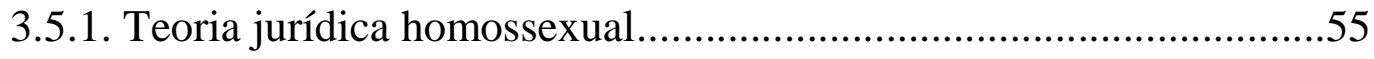

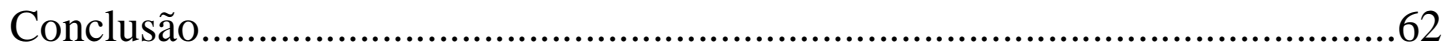

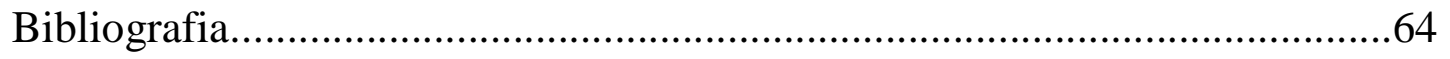

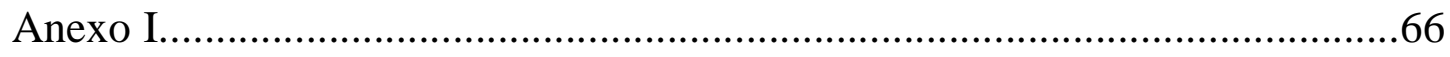

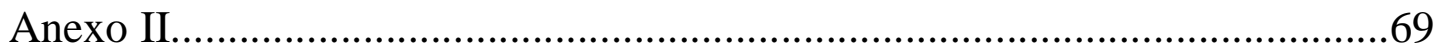




\section{INTRODUÇÃO}

Desde o surgimento da humanidade o homem se encontra em constante busca pelo transcendente, pelo sobrenatural, pelo absoluto, se apegando às mais diversas crenças, de onde foram surgindo as religiões. Isto ocorre de tal forma que enseja o pensamento de que essa procura faz parte de sua própria natureza, pois em rápida observação às culturas, ao modo de pensar dos variados povos em todo o mundo, verifica-se a forte influência da religião dominante naquele local. Tanto é assim, que mesmo aqueles que se dizem ateus, que não creem em um ser transcendental, expendem bastante tempo tentando explicar por que Deus não existe, por que não acreditam em nada sobrenatural. Ou seja, mesmo não crendo, falam extensivamente no assunto.

Além disso, outro fato que reforça a indagação sobre a inerência de tal assunto à natureza humana é a maneira como as pessoas reagem quando têm sua fé atacada, o que é facilmente percebido através das grandes e principais guerras da humanidade, as quais tiveram como pano de fundo, em sua maioria, uma questão religiosa.

O tema religioso adquiriu ainda maior importância com a criação do Estado, mais especificamente o Estado laico de direito, e o crescente aparecimento de diferentes religiões com suas mais variadas práticas e dogmas. A partir desse acontecimento, surge um conflito além daqueles que sempre existiram entre as próprias religiões. Tal conflito se dá entre o Estado e estas últimas, e consiste na delimitação da liberdade de crença frente às normas do Estado, e até que ponto este pode interferir dentro das confissões religiosas, principalmente quando se está em questão direitos fundamentais do homem. Percebe-se, portanto, a atualidade do tema e suas implicações práticas.

Necessário é dizer que o direito à liberdade religiosa constitui um dos elementos estruturantes do Estado constitucional, o qual foi desenvolvido 
como reação contra o autoritarismo da cristandade medieval e contra o regalismo dos monarcas absolutos do Estado moderno, que entendiam ter o direito de impor sua religião a seus súditos. Deste modo, a liberdade religiosa se originou no processo de democratização da religião, que foi propiciado pelo surgimento da imprensa, a qual facilitou o acesso aos escritos religiosos, e pela crítica protestante ao cristianismo imperial, centralizado, autoritário e hierarquizado. $\mathrm{O}$ direito à liberdade religiosa pode ser considerado como legado do pensamento liberal, que permeou a revolução estadunidense e foi fundamental para a elaboração da Constituição norte-americana. Essa mesma corrente do pensamento político também influenciou o constitucionalismo das demais nações, principalmente as ocidentais. Hoje, a liberdade religiosa está presente na maioria dos países, o que não significa que não existam discussões, conflitos e ataques a ela.

O direito à liberdade religiosa é um direito fundamental do ser humano, e no Brasil é assegurado pela Constituição Federal de 1988 e pelos tratados internacionais que versam sobre direitos humanos. Mas o que torna essa questão mais relevante neste país é o fato de sermos uma sociedade de grande sincretismo, o que acaba por gerar maiores conflitos.

Ao estudar o assunto "liberdade religiosa", é possível verificar que há uma restrita bibliografia a respeito desse tema, e que os doutrinadores, em geral, se limitam a tratar do direito à liberdade religiosa individual, abordando normalmente os mesmos temas, os quais são mais comuns de gerar problemas e embates no campo jurídico, e que possuem como conteúdo, em sua grande maioria, o choque entre os direitos fundamentais. Todavia, apesar de não ser muito falado, o direito fundamental à liberdade religiosa também é um direito das confissões religiosas, o qual também merece atenção, visto que a cada dia surgem novas ameaças a tal direito, seja por movimentos das mais diversas espécies, seja por demandas ao Judiciário, que erroneamente acaba interferindo no âmbito interno das religiões e ferindo o seu direito. Todos os dias as 
confissões são criticadas por suas doutrinas, suas decisões, seus posicionamentos, de cunho, algumas vezes, segregacionista.

Contudo, independentemente da peculiaridade de cada entidade religiosa, cumpre destacar que no contexto de um Estado laico, onde impera a separação deste e da religião, a liberdade religiosa tem como um dos seus objetivos proteger as confissões religiosas contra uma intervenção abusiva do Estado, e garantir a sua autonomia doutrinal e seus direitos de autocompreensão, autodeterminação, autodefinição, que serão a seu tempo discutidos.

Com isso, pretende-se analisar essa particularidade do tema "liberdade religiosa", focando o direito à liberdade religiosa titulado pelas religiões, elencando suas implicações e limites no âmbito das confissões, além dos pressupostos para a liberdade religiosa em geral. 


\section{Capítulo I \\ CONSIDERAÇÕES PRELIMINARES ACERCA DA LIBERDADE RELIGIOSA}

\section{I.1. Introdução}

Ao se tratar do tema liberdade religiosa, é necessário, primeiramente, se falar em "Estado laico" e "democracia". Assim, deve-se remeter, em apertada síntese, à história do mundo ocidental, na qual houve um momento em que o poder político deixou de ser legitimado pelo sagrado, e a soberania não mais residiu em uma única pessoa, o monarca. Neste processo, em alguns casos as monarquias passaram a ser constitucionais em vez de absolutas, e em outros foram estabelecidas repúblicas, a exemplo dos Estados Unidos, da França e do México. Com isso, a soberania foi passada ao povo, razão esta pela qual, como será visto a seguir, a democracia e a laicidade estão intrinsecamente ligadas e fortemente presentes no direito à liberdade religiosa, uma vez que esta surgiu a partir das guerras religiosas e solidificou-se na transição do Estado moderno e monárquico para o Estado constitucional e republicano.

\section{I.2. Democracia e laicidade}

A democracia é o regime em que o poder emana do povo e é exercido em seu nome. Desta maneira, é certa a imprescindibilidade, para que seja legítima, de instrumentos antimajoritários, sendo de extrema importância a adoção dos princípios da liberdade e da igualdade, sob pena de morte da democracia, que sem tais princípios se tornaria ditadura da maioria. Portanto, o povo é livre para escolher seus representantes, e a sua liberdade apenas 
encontra limites nas proibições legais. Foi para que essa liberdade fosse protegida que foram constituídos os direitos e garantias fundamentais, os quais são indisponíveis.

Pode-se dizer, então, nas palavras de Aldir Guedes Soriano, que "não há direitos civis e políticos sem democracia, nem tampouco liberdade religiosa. A democracia é o substrato que permite o exercício da liberdade religiosa e, também, dos demais direitos fundamentais da pessoa humana". ${ }^{1}$ Diz-se, a luz de tais fundamentos, que liberdade religiosa e democracia são inseparáveis. Assim, com o intuito de demonstrar a veracidade de tais afirmações, isto é, que liberdade religiosa e democracia se coadunam perfeitamente, o autor continua:

De acordo com os mais recentes relatórios de pesquisa, as violações do direito à liberdade religiosa estão espalhadas por todo o mundo, entretanto a situação nos países democráticos é sensivelmente melhor. Estados democráticos são os que oferecem melhores condições para o exercício das liberdades públicas relacionadas à religião. Por outro lado, é notória a gravidade das violações nos Estados nãodemocráticos, considerados não-livres.

Quanto à laicidade, esta pode ser definida, nas palavras de Roberto Blancarte, como "um regime social de convivência, cujas instituições políticas estão legitimadas principalmente pela soberania popular e já não mais por elementos religiosos". ${ }^{2}$ Ela supõe que a legitimidade do Estado e das suas normas não é baseada em doutrinas religiosas, e nem submetida à aprovação de alguma entidade religiosa, mas na soberania dos cidadãos, livres e iguais, razão esta pela qual é adotada na maioria das democracias ocidentais contemporâneas.

De acordo com o Relatório da Comissão de Reflexão sobre a Aplicação do Princípio da Laicidade na República (França, 2003), também conhecido

\footnotetext{
${ }^{1}$ SORIANO, Aldir Guedes. Direito à liberdade religiosa sob a perspectiva da democracia liberal. In: SORIANO, Aldir; MAZZUOLI, Valério (Org.). Direito à liberdade religiosa: desafios e perspectivas para o século XXI. Belo Horizonte: Editora Fórum, 2009. p. 164.

${ }^{2}$ BLANCARTE, Roberto. O porquê de um Estado laico. In: LOREA, Roberto Arriada (Org.). Em defesa das liberdades laicas. Porto Alegre: Editora Livraria do Advogado, 2008. p. 19.
} 
como Relatório da Comissão Stasi, "a laicidade supõe a independência entre o poder político e as diferentes opções espirituais ou religiosas. Elas não exercem influência sobre o Estado e nem este sobre elas". Deste modo, não há, em um Estado laico, privilégios concedidos a alguma opção religiosa, pois a laicidade implica na neutralidade do Estado, o qual é fundado no princípio da igualdade.

Nota-se, dessa forma, que a liberdade religiosa é um dos mais fundamentais corolários do Estado laico e democrático, compondo o rol de dispositivos antimajoritários e sendo caracterizada como uma garantia fundamental do cidadão. Nesta linha de raciocínio, Daniel Sternick, em seu trabalho acerca da liberdade religiosa no Estado de Israel, assinala da seguinte forma:

(...) um Estado rigorosamente laico e democrático é aquele que se coloca em posição de neutralidade em relação às religiões e no qual o poder político não encontra seu fundamento de validade e legitimidade nas concepções sagradas. De fato, o Estado reconhece o fenômeno religioso e inclusive tutela o seu exercício, colocando as diferentes confissões religiosas em um mesmo plano e com igual liberdade. Ele não privilegia os fiéis de uma religião em detrimento de outros e separa, de forma explícita, as instituições públicas das crenças religiosas. ${ }^{3}$

Daniel Sarmento diz que a laicidade estatal é um princípio que opera em duas direções. Por um lado ela salvaguarda o Estado de influências indevidas que provenham do âmbito religioso, impedindo a confusão entre "o poder secular e democrático, em que estão investidas as autoridades públicas, e qualquer confissão religiosa, inclusive a majoritária”. Do outro lado, o qual será o foco do presente trabalho, a laicidade protege as diversas religiões do risco de intervenções abusivas do Estado em suas questões internas, que dizem respeito a "aspectos como os valores e doutrinas professados, a forma de

\footnotetext{
${ }^{3}$ STERNICK, Daniel. O conceito de laicidade no Estado judeu: controvérsias em torno da liberdade religiosa em Israel. In: LEITE, Fábio (Org.). Cadernos do Departamento de Direito da Pontifícia Universidade Católica do Rio de Janeiro. Rio de Janeiro: Editora PUC-RIO, 2010. p. 98.
} 
cultuá-los, a sua organização institucional, os seus processos de tomada de decisões, a forma e o critério de seleção dos seus sacerdotes e membros, etc". Nesta direção, a laicidade opõe-se ao regalismo, que ocorre quando existe uma subordinação das entidades religiosas ao Estado no que concerne a questões de natureza não-secular. ${ }^{4}$

O mesmo autor ainda reforça que a laicidade é qualificada como uma verdadeira garantia institucional da liberdade religiosa individual, porque "a promiscuidade entre os poderes públicos e qualquer credo religioso, por ela interditada, ao sinalizar o endosso estatal de doutrinas de fé, pode representar uma coerção, ainda que de caráter psicológico, sobre os que não professam aquela religião". 5

É importante observar que laicidade não significa abolir a religião ou a adoção pelo Estado de uma perspectiva ateísta, pois, na verdade, a negação da existência de Deus é um posicionamento religioso que não pode ser privilegiado em detrimento de outras crenças. O Estado laico não deve perseguir as religiões, nem promover a religiosidade, mas buscar o mínimo de restrição com o máximo de liberdade, sempre focando o respeito à diversidade religiosa, contemplando crentes e não crentes.

A laicidade é remetida à separação entre Estado e Religião, conforme descrito por Locke na seguinte frase, "O Estado nada pode em matéria puramente espiritual, e a Igreja nada pode em matéria temporal". Desta maneira, diz-se que o Estado laico não assume uma confissão religiosa como própria, ao contrário do Estado teocrático, mas reflete um método de pensamento que defende a autonomia das instituições públicas, da sociedade civil, do ordenamento jurídico em relação às autoridades religiosas, às organizações confessionais, à fé e ao espiritual.

\footnotetext{
${ }^{4}$ SARMENTO, Daniel. O porquê de um Estado laico. In: LOREA, Roberto Arriada (Org.). Em defesa das liberdades laicas. Porto Alegre: Editora Livraria do Advogado, 2008. p. 190-191.

${ }^{5}$ Idem.
} 
A separação entre Estado e religião é tida como pressuposto para que haja plena liberdade religiosa. Isto não quer dizer que Estados que possuam uma religião como oficial não tenham ou não possam ter o direito à liberdade religiosa, mas que este será mais dificilmente conseguido. André Ramos Tavares assevera que a neutralidade do Estado não é essencial para a existência de pluralidade religiosa, mas que esta apenas pode "aflorar plenamente em Estados que adotam o postulado separatista e a postura da neutralidade religiosa". ${ }^{6}$ Prossegue o autor:

Quer dizer que nos Estados confessionais pode haver, como afirmado anteriormente, liberdade religiosa, mas será ela mitigada em virtude justamente do tratamento preferencial e privilegiado resguardado à religião oficial. Ter-se-á, nesta última hipótese, provavelmente, mais uma tolerância do que uma plena liberdade religiosa, especialmente no que tange à sua divulgação e práticas.

Discordando da associação comumente feita entre laicidade e separação dos assuntos do Estado e da Igreja, o que ocorre pelo fato de os Estados laicos, na prática, terem adotado medidas de separação, Roberto Blancarte defende que "existem Estados que não conhecem a separação formal e no entanto suas formas de governo são essencialmente democráticas, por isso não requerem uma legitimação eclesiástica ou sagrada". O autor faz referência ao caso francês como a melhor prova de que pode existir laicidade sem separação, pois a escola laica foi desenvolvida no último terço do século XIX, e a separação entre Estado e Igreja apenas ocorreu, na França, a partir de 1905. Desse modo, Roberto Blancarte entende que é possível a existência de países laicos sem que haja separação entre Estado e Igreja. ${ }^{7}$

Neste contexto, Maria Emília Corrêa da Costa afirma que a ideia de laicidade e separação entre Estado e Igreja não é pressuposto da liberdade

\footnotetext{
${ }^{6}$ TAVARES, André Ramos. Religião e neutralidade do Estado. In: SORIANO, Aldir; MAZZUOLI, Valério (Org.). Direito à liberdade religiosa: desafios e perspectivas para o século XXI. Belo Horizonte: Editora Fórum, 2009. p. 57.

${ }^{7}$ BLANCARTE, Roberto. Op. Cit. p. 20.
} 
religiosa, mas é elemento que fortalece a preservação desse direito fundamental. $^{8}$

A partir do Decreto n. ${ }^{\circ}$ 119-A, de 07.01.1890, de autoria de Ruy Barbosa, foi instaurado o modelo de separação entre a Igreja e o Estado, tornando o Estado brasileiro em um Estado laico e, com isso, passando a respeitar todas as religiões. Tal modelo foi recepcionado pela nova ordem republicana em 1891. Na ordem constitucional vigente, o princípio da laicidade foi expressamente consagrado em seu artigo 19, inciso I, vedando expressamente à União, aos Estados, ao Distrito Federal e aos Municípios "estabelecer cultos religiosos ou igrejas, subvencioná-los, embaraçar-lhes o funcionamento ou manter com eles ou seus representantes relações de dependência ou aliança, ressalvada, na forma da lei, a colaboração de interesse público".

Cumpre salientar que a liberdade religiosa é um direito fundamental consagrado nas constituições dos países democráticos, assim como nos principais tratados internacionais e está preconizada em nossa Constituição Federal de 1988, no seio dos direitos e garantias fundamentais, no artigo $5^{\circ}$, incisos VI (liberdade de consciência e de crença; livre exercício dos cultos religiosos; proteção aos locais de culto e suas liturgias), VII (assistência religiosa nas entidades civis e militares de internação coletiva) e VIII (não privação de direitos por motivo de crença religiosa); ao tratar da organização do Estado, no artigo 19, inciso I; no capítulo das forças armadas, no artigo 143, $\S \S 1^{\circ}$ e $2^{\circ}$; no sistema tributário nacional, no artigo 150, inciso VI, "b"; quanto à ordem social, atinente à educação, há previsão no artigo $210, \S 1^{\circ}$ e $\operatorname{artigo}$ 213 , caput, inciso II; e no capítulo da família, no artigo $226, \S 2^{\circ}$.

\footnotetext{
${ }^{8}$ COSTA, Maria Emília Corrêa da. Apontamentos sobre a liberdade religiosa e a formação do Estado laico. In: LOREA, Roberto Arriada (Org.). Em defesa das liberdades laicas. Porto Alegre: Editora Livraria do Advogado, 2008. p. 97.
} 
Trata-se, portanto, de uma liberdade pública ou, como se achar melhor, de uma prerrogativa individual oponível ao Estado. ${ }^{9}$ Este, por sua vez, possui obrigações negativas e positivas de fazer ou atuar frente a este direito. Neste diapasão, Humberto Martins menciona, como a "última das facetas da liberdade religiosa", "a atuação ponderada do Estado em permitir o pluralismo de crenças, seja abstendo-se de refreá-lo, seja atuando comissivamente para prestigiá-lo". ${ }^{10}$ Desta maneira, o Estado tem o dever de não atuar naquelas áreas reservadas ao indivíduo, e o de atuar protegendo esse direito em face de eventuais violações por parte de particulares ou autoridades. Seguindo esta linha de pensamento, Jónatas Machado assevera:

O direito à liberdade religiosa pretende, fundamentalmente, recortar em torno de indivíduos e de grupos um premímetro de liberdade de opção e actuação religiosa que o Estado não pode vulnerar. Dele procedem, a um tempo, direitos subjectivos de defesa e normas definitórias de competências negativas estaduais. ${ }^{11}$

Isto ocorre porque cabe ao cidadão o direito de escolher suas crenças e de viver ou não em conformidade com os ditames de sua consciência religiosa, ateia ou agnóstica, o que está totalmente conectado com o princípio da autodeterminação. No plano subjetivo, a autodeterminação diz respeito às escolhas pessoais de caráter fundamental. ${ }^{12}$

Nos dizeres de Humberto Martins, "o plano da autodeterminação estaria no poder de cada indivíduo gerir livremente a sua esfera de interesses, orientando a sua vida de acordo com as suas preferências". ${ }^{13}$ Assim, o direito à

\footnotetext{
${ }^{9}$ SORIANO, Aldir Guedes. Liberdade religiosa no Direito constitucional e Internacional. $1^{\text {a }}$ ed. São Paulo: Editora Juarez de Oliveira, 2002. p. 5.

${ }^{10}$ MARTINS, Humberto. Liberdade religiosa e estado democrático de direito. In: SORIANO, Aldir; MAZZUOLI, Valério (Org.). Direito à liberdade religiosa: desafios e perspectivas para o século XXI. Belo Horizonte: Editora Fórum, 2009. p. 100.

${ }^{11}$ MACHADO, Jónatas. Liberdade religiosa numa comunidade constitucional inclusiva: Dos direitos da verdade aos direitos dos cidadãos. Coimbra: Coimbra Editora, 1996. p. 199.

${ }_{12}^{12}$ MARTINS, Humberto. Op. Cit. p. 99.

${ }^{13}$ Idem.
} 
liberdade religiosa é uma expressão da dignidade humana e expressa o direito de autodeterminação do sujeito de direitos.

Este direito de escolha do indivíduo, como mencionado acima, está ligado ao princípio da dignidade da pessoa humana, o qual é o fundamento cardeal do direito à liberdade religiosa. ${ }^{14}$ Tangenciando a questão de ligação entre o princípio da dignidade da pessoa humana e o direito à liberdade religiosa, Jónatas Machado diz que a doutrina e a jurisprudência estão sempre a frisar a íntima relação que há entre a liberdade de consciência, liberdade religiosa e a dignidade da pessoa humana, ao mesmo tempo que sublinham que este é o valor mais elevado dos direitos fundamentais. ${ }^{15}$ Sentencia o autor que o princípio da dignidade da pessoa humana "repousa na dignidade do indivíduo enquanto sujeito dotado de competência moral-prática, insusceptível de ser tratado como um simples meio para atingir um fim". ${ }^{16}$

\section{I.3. Dimensão jurídico-subjetiva da liberdade religiosa}

Em primeiro lugar, cumpre abordar a posição da doutrina brasileira acerca do presente tema. Esta prega que a liberdade religiosa decorre da liberdade de pensamento, a exemplo de José Afonso da Silva, que assinala que aquela, em sua exteriorização, é forma de manifestação de pensamento, embora possua conteúdo mais complexo devido às implicações que gera. ${ }^{17}$ No mesmo sentido entende Aldir Guedes Soriano, o qual, em concordância com José Cretella Júnior, diz que a liberdade de consciência se equipara à liberdade de crença, pois ambas se referem a questões internas do ser humano, e que a

\footnotetext{
${ }^{14}$ SORIANO, Aldir Guedes. Direito à liberdade religiosa sob a perspectiva da democracia liberal. Op. Cit. 169 p.

${ }^{15}$ MACHADO, Jónatas. Op. Cit. p. 192.

${ }^{16}$ Idem.

${ }^{17}$ SILVA, José Afonso da. Curso de Direito Constitucional Positivo. $27^{\mathrm{a}}$ ed. São Paulo: Malheiros editores, 2006. p. 248.
} 
liberdade religiosa está inserida no direito à liberdade de pensamento (lato sensu), pois, como afirma Pontes de Miranda, aquela é especialização desta. ${ }^{18}$

Seguindo uma linha contrária ao defendido pela doutrina pátria, Jónatas Machado refere-se à compreensão da liberdade de consciência como matriz da liberdade religiosa, ressaltando que "não existindo qualquer critério inequívoco e indiscutível de verdade religiosa, as opções de fé são relegadas, numa ordem constitucional livre e democrática, para o foro da consciência individual". Assim, levando-se em consideração que "as pessoas mantêm uma grande variedade de valores e interesses substantivos diferentemente articulados e hierarquizados por um amplo leque de sistemas éticos", entende o autor:

Compete a um modelo de pessoas jurídicas comunicativamente livres e iguais assegurar que os processos de articulação e hierarquização de valores e interesses decorram num contexto de liberdade, dentro de um âmbito de reserva pessoal de intimidade constitucionalmente protegida. ${ }^{19}$

No mesmo sentido, entende Jayme Weingartner Neto, que reitera o pensamento de Jónatas Machado da seguinte forma:

Lançar mão da liberdade de consciência como matriz para a liberdade religiosa (...) tem a vantagem de apontar para os valores fortes da consciência e da razão individuais, com respaldo axiológico para o cluster right da liberdade religiosa, além de harmonizar-se, em princípio de forma mais adequada, ao texto da Constituição Federal de 1988, notadamente ao ponto de Arquimedes representado pelo inciso VI do artigo $5^{\circ}$, que parte da inviolabilidade da liberdade de consciência para, a seguir, enunciar o direito à liberdade religiosa como um todo. ${ }^{20}$

De fato, considerar a liberdade religiosa como uma decorrência da liberdade de consciência, e não da mera liberdade de pensamento, nas palavras

\footnotetext{
${ }^{18}$ SORIANO, Aldir Guedes. Liberdade religiosa no direito constitucional e internacional. Op. Cit. p. 92.

${ }^{19}$ MACHADO, Jónatas. Op. Cit. p. 193-194.

${ }^{20}$ NETO, Jayme Weingartner. Liberdade religiosa na Constituição: fundamentalismo, pluralismo, crenças, cultos. Porto Alegre: Livraria do advogado editora, 2007. p. 91.
} 
de Fábio Carvalho Leite, "confere à liberdade religiosa um status distinto daquele conferido às simples manifestações de pensamento, e certamente mais adequado à natureza do fenômeno religioso". Deste modo, o direito à liberdade religiosa diz respeito a um direito mais amplo de liberdade de consciência, e não a uma corrente de ideias ou de pensamento. ${ }^{21}$

Após tais considerações, cabe dizer que a dimensão jurídico-subjetiva da liberdade religiosa, ou, como utilizado por Jónatas Machado, a liberdade religiosa individual, engloba a liberdade de crença e de culto, e a liberdade de organização religiosa, conforme se verá nos seguintes tópicos.

\section{I.3.1. Liberdade de crença e de culto}

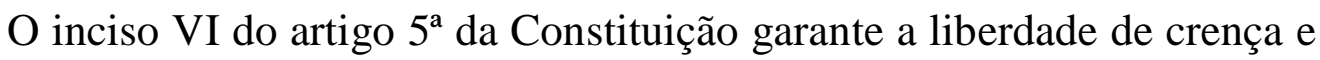
de culto, garantindo que "é inviolável a liberdade de consciência e de crença, sendo assegurado o livre exercício dos cultos religiosos e garantida, na forma da lei, a proteção aos locais de culto e as suas liturgias".

Falando-se em liberdade de crença, inicialmente, deve-se dizer que esta também é protegida pelo inciso VII do mesmo artigo, o qual aduz que "ninguém será privado de direitos por motivo de crença". Com isso, ela visa proteger o forum internum, precludindo a sujeição das opções de fé a quaisquer pressões, diretas ou indiretas, explícitas ou implícitas, criando uma esfera jurídico-subjetiva ao redor do indivíduo, cujo perímetro os poderes públicos e as entidades privadas devem respeitar. ${ }^{22}$

É assegurado, pois, à pessoa, ausente de qualquer pressão ou coação, a

possibilidade de responsabilizar-se por suas decisões éticas e existenciais, sendo guiada por suas próprias convicções. Deste modo, o indivíduo é livre

\footnotetext{
${ }^{21}$ LEITE, Fábio Carvalho. Estado e religião no Brasil: A liberdade religiosa na Constituição de 1998. Rio de Janeiro. 2008. Tese (Doutorado em Direito). Departamento de Direito da UERJ.
} 
para crer ou não naquilo que quiser, nas divindades, no transcendental, e também para mudar de crença ou religião quando bem entender. Essa liberdade poderia ser chamada de a-religiosa, pois a crença pode ser exercida em qualquer direção e contar, em qualquer situação, com a neutralidade e nãoconfessionalidade do Estado, que deve igual consideração e respeito por todos os cidadãos, ignorando se o indivíduo crê e em que crê. ${ }^{23}$

Conforme ensina Humberto Martins, "a liberdade de religião implica escolher uma fé religiosa, alterar seu vínculo com a igreja escolhida ou mesmo deixar de acreditar em determinada expressão da religiosidade". ${ }^{24}$ Esta descrição refere-se à liberdade de crença.

Já a liberdade de culto é normalmente caracterizada como forma de exteriorização da crença, podendo-se manifestar através de ritos, cultos, reuniões, etc. Ela é referida, além do artigo $5^{\circ}$ já mencionado, no artigo 150, VI, b, que estatui a imunidade fiscal sobre "templos de qualquer culto", e do artigo 19, I, que veda aos poderes públicos embaraçar o exercício dos cultos religiosos.

Acerca da liberdade de culto explica José Afonso da Silva:

A religião não é apenas sentimento sagrado puro. Não se realiza na simples contemplação do ente sagrado, não é simples adoração a Deus. Ao contrário, ao lado de um corpo de doutrina, sua característica básica se exterioriza na prática de ritos, no culto, com suas cerimônias, manifestações, reuniões, fidelidades aos hábitos, às tradições, na forma indicada pela religião escolhida. ${ }^{25}$

Devido a essa ideia de que a liberdade de culto é a exteriorização da liberdade de crença, costuma-se dizer que a primeira é passível de restrições, enquanto que a segunda, por dizer respeito ao forum internum do indivíduo, não possuiria limites. Todavia, a liberdade de crença não se configura apenas

\footnotetext{
${ }^{22}$ MACHADO, Jónatas. Op. Cit. p. 220.

${ }^{23}$ NETO, Jayme Weingartner. Op. Cit. p. 114.

${ }^{24}$ MARTINS, Humberto. Op. Cit. p. 101.

${ }^{25}$ SILVA, José Afonso da. Op. Cit. p. 249.
} 
como o direito de se ter uma crença, pois se realmente fosse uma liberdade interna não haveria motivos para ser tutelada, pois ao Direito não interessa a liberdade interna. A liberdade de crença, na verdade, é o direito de exprimir uma crença, e, portanto, assim como a liberdade de culto, a liberdade de crença também implica em uma exteriorização. ${ }^{26}$ Aliás, como assinala Jónatas Machado, "a liberdade religiosa não seria adequadamente tutelada se admitisse uma tão estrita como simplificadora bipolaridade entre crença (belief) e conduta (action), que resultasse numa generosa proteç̧ão da primeira e na desvalorização da segunda". ${ }^{27}$

Com isso, é importante observar que a liberdade de crença e a de culto são formas de manifestação exterior da religião professada, e ambas são passíveis de restrição, uma vez que não existe direito absoluto no ordenamento jurídico. Mesmo a simples expressão individual de uma crença pode ser restringida, contudo, em regra, a liberdade religiosa "é um direito de alcance muito amplo, que, se não é efetivamente um direito ilimitado, como visto, é o que mais disso se aproxima". ${ }^{28}$ Cabe, nesse sentido, mencionar que as constituições brasileiras de 1946 e 1967 previam que a liberdade religiosa deveria ser compatível com a ordem pública e os bons costumes, previsão esta que foi retirada da atual Carta da República, até porque, como salienta José Afonso da Silva, "parece impensável uma religião cujo culto, por si, seja contrário aos bons costumes e à ordem pública. Ademais, tais conceitos são vagos, indefinidos, e mais serviram para intervenções arbitrárias do que de tutela desses interesses gerais". ${ }^{29}$ Assim, quanto às restrições legítimas às liberdades de crença e de culto, para não se falar na própria liberdade religiosa, elas serão mais comuns à medida que envolvam uma conduta que ultrapasse a esfera meramente individual e passe a atingir terceiros que não compartilham

\footnotetext{
${ }^{26}$ LEITE, Fábio Carvalho. Op. Cit.

${ }^{27}$ MACHADO, Jónatas. Op. Cit. p. 222.

${ }^{28}$ LEITE, Fábio Carvalho. Op. Cit.

${ }^{29}$ SILVA, José Afonso da. Op. Cit. p. 250.
} 
do mesmo credo. Vale destacar o entendimento de Aldir Guedes Soriano: "Se a pessoa humana tem o direito de escolha em razão de sua dignidade, então o Estado-juiz não pode restringir as liberdades públicas injustificadamente, alicerçado, apenas, em critérios de conveniência e oportunidade". ${ }^{30}$

Por fim, acerca das liberdades de crença e culto, conclui-se que a diferença entre elas perde importância pelo fato de a Constituição de 1988 ter assegurado a inviolabilidade da primeira e o livre exercício da segunda. ${ }^{31}$

\section{I.3.2. Liberdade de organização religiosa}

A liberdade de organização religiosa se refere à possibilidade de estabelecimento e organização das instituições religiosas e suas relações com o Estado. Ressalte-se que o Decreto n. ${ }^{\circ}$ 119-A, através do qual foi instituído o Estado laico no Brasil, conforme já visto anteriormente, reconheceu personalidade jurídica a todas as confissões religiosas.

A organização religiosa é assegurada, assim como a liberdade de crença e de culto, pelo artigo $5^{\circ}$, inciso VI da Constituição. Portanto, com base neste artigo e no artigo 19, inciso I, da nossa Carta Magna ("É vedado à União, aos Estados, ao Distrito Federal e aos Municípios estabelecer cultos religiosos ou igrejas, subvencioná-los, embaraçar-lhes o funcionamento ou manter com eles ou seus representantes relações de dependência ou aliança, ressalvada, na forma da lei, a colaboração de interesse público") não pode o Estado embaraçar as manifestações religiosas se estas estiverem organizadas na forma

da lei. Além disso, cumpre ao Estado proteger os locais de culto através de seu poder de polícia. É vedado ao Estado subsidiar religiões e estabelecer cultos.

\footnotetext{
${ }^{30}$ SORIANO, Aldir Guedes. Direito à liberdade religiosa sob a perspectiva da democracia liberal. Op. Cit. p. 175.

${ }^{31}$ LEITE, Fábio Carvalho. Op. Cit.
} 
Com o fim de se entender melhor a vedação do artigo 19, inciso I, da Constituição, Pontes de Miranda o destrincha:

Estabelecer cultos religiosos está em sentido amplo: criar religiões ou seitas, ou fazer igrejas ou quaisquer postos de prática religiosa, ou propaganda. Subvencionar cultos religiosos está no sentido de concorrer, com dinheiro ou outros bens da entidade estatal, para que se exerça a atividade religiosa. Embaraçar o exercício dos cultos religiosos significa vedar, ou dificultar, limitar ou restringir a prática, psíquica ou material, de atos religiosos ou manifestações de pensamento religioso. ${ }^{32}$

Além da separação e colaboração entre Igreja e Estado, José Afonso também insere no tema "liberdade de organização religiosa" a assistência religiosa, o ensino religioso e o casamento religioso, como será visto rapidamente:

- Assistência religiosa: A lei assegura a prestação de assistência religiosa nas entidades civis e militares de internação coletiva, como penitenciárias, casas de detenção, casas de internação de menores, etc.

- Ensino religioso: De acordo com o artigo $210, \S 1^{\circ}$, da Constituição, as escolas públicas de ensino fundamental devem possuir, como matéria facultativa, o ensino religioso. É um direito do aluno ter a possibilidade de matricular-se na matéria, mas não é um dever seu fazê-lo.

- Casamento religioso: O casamento religioso terá efeito civil nos termos da lei (artigo 226, $\S \S 1^{\circ}$ e $2^{\circ}$ ).

\footnotetext{
32 MIRANDA, Pontes de. Comentários à Constituição de 1967. Tomo II. São Paulo: RT, 1967. p. 185.
} 


\section{Capítulo II \\ A LIBERDADE RELIGIOSA TITULADA PELAS ENTIDADES RELIGIOSAS}

\section{II.1. Igrejas e confissões religiosas}

Ausente de dúvidas é o direito à liberdade religiosa garantido ao indivíduo pela Constituição Federal de 1988 e por tratados internacionais. Deste modo, é certo que a cada pessoa assiste a possibilidade de tomar, responsavelmente, as suas decisões éticas e existenciais, de acordo com os ditames da sua consciência, livre de qualquer pressão ou coação. Todavia, a liberdade religiosa não é um direito gozado apenas pelas pessoas físicas, mas também pelas pessoas jurídicas, leiam-se aqui igrejas, entidades religiosas, grupos religiosos, etc, uma vez que os indivíduos podem utilizar a liberdade religiosa da maneira como bem entenderem, professando sua religião individual ou coletivamente.

Assim, depreende-se que a liberdade religiosa pode ser expressa tanto na crença individual, como coletiva, isto é, no âmbito das entidades religiosas. Desta forma, verifica-se que a titularidade dos direitos fundamentais não é limitada constitucionalmente às pessoas físicas, mas é estendida, da mesma maneira, às pessoas jurídicas ou coletivas. ${ }^{33}$ Frise-se que "pessoas coletivas" é uma expressão comumente utilizada em Portugal. Aliás, neste país usa-se "liberdade religiosa coletiva" para tratar do direito à liberdade religiosa de que também gozam as entidades religiosas, pois há expressa referência à vinculação das "pessoas coletivas" aos direitos e deveres fundamentais na

\footnotetext{
${ }^{33}$ MACHADO, Jónatas. Liberdade religiosa numa comunidade constitucional inclusiva: Dos direitos da verdade aos direitos dos cidadãos. Coimbra: Coimbra Editora, 1996. p. 234.
} 
Constituição Portuguesa, sendo consagrado o princípio da universalidade no artigo $12^{\circ}$, n. $^{\circ} 2$, da mesma. ${ }^{34}$

No que tange à titularidade do direito à liberdade religiosa, Aldir Guedes Soriano exprime:

Qualquer pessoa humana é titular ativo do direito à liberdade religiosa (...), conforme a Declaração Universal dos Direitos Humanos de 1948. Uma vez que a liberdade religiosa também apresenta dimensão coletiva ou institucional, não se pode deixar de incluir as igrejas, mesquitas, sinagogas e centros espíritas (todas as organizações religiosas) no rol dos titulares ativos. Assim, as pessoas jurídicas de direito privado, associações e fundações também podem ser titulares ativos. ${ }^{35}$

Cumpre salientar que a temática "liberdade religiosa das pessoas jurídicas" não é comum na doutrina brasileira, referindo-se, a maior parte dos comentadores, aos direitos das igrejas no plano da liberdade de organização e no âmbito do princípio da separação. ${ }^{36}$

Do ponto de vista jurídico-constitucional, os direitos das pessoas jurídicas não são menos dignos de proteção do que os direitos individuais. No entanto, os direitos, liberdades e garantias possuem uma presunção a favor da sua dimensão subjetiva, sendo certo que as pretensões das confissões religiosas se encontram limitadas pelos direitos de autonomia religiosa individual. ${ }^{37}$ No caso do fenômeno religioso, a titularidade de direitos fundamentais das pessoas jurídicas ganha particular importância. Isto é explicado pela história, pois ela demonstra a existência e influência de inúmeros grupos que surgem da dinâmica social do homem e da religião. No caso do Cristianismo, por exemplo, "a ideia de assembleia (ecclesia), marcou tão profundamente os hábitos sociais que se torna difícil de conceber a religião desligada da sua

\footnotetext{
${ }^{34}$ NETO, Jayme Weingartner. Liberdade religiosa na constituição: fundamentalismo, pluralismo, crenças, cultos. Porto Alegre: Livraria do Advogado, 2007. p. 131.

${ }^{35}$ SORIANO, Aldir Guedes. Direito à liberdade religiosa sob a perspectiva da democracia liberal. In: SORIANO, Aldir; MAZZUOLI, Valério (Org.). Direito à liberdade religiosa: desafios e perspectivas para o século XXI. Belo Horizonte: Editora Fórum, 2009. p. 177.

${ }^{36}$ NETO, Jayme Weingartner. Op. Cit. p. 132.

${ }^{37}$ MACHADO, Jónatas. Op. Cit. p. 234.
} 
dimensão associativa". Uma das formas mais comuns e marcantes pelas quais o indivíduo exercita sua liberdade religiosa é aderindo a uma "comunidade moral de natureza religiosa". Por isso, devido ao caráter social do fenômeno religioso, o reconhecimento do direito à liberdade religiosa tem como corolário o respeito pela autonomia das formações sociais resultantes, normalmente, de tal fenômeno. ${ }^{38}$

Nesse sentido, cabe mencionar que uma interferência estatal em questões internas das confissões religiosas ocasiona um duplo impacto, pois atinge não somente a dimensão coletiva da liberdade religiosa, como também a dimensão individual. Percebe-se, portanto, que as duas dimensões, individual e coletiva, acabam por ter forte ligação, e que o principal fundamento para a liberdade religiosa das confissões é o "escoramento nas convicções da consciência individual", o que significa que a liberdade coletiva "serve a atualização da liberdade pessoal". Isto, todavia, não significa que as comunidades religiosas sejam reduzidas a um mero agregado de indivíduos, pois, na verdade, sua condição atual é de atores religiosos, políticos e sociais independentes. $^{39}$

Jayme Weingartner demonstra que mesmo em Portugal a questão possui controvérsias. Deste modo, apresenta dois entendimentos contrários, sendo um o de Jorge Miranda, segundo o qual os direitos fundamentais são direitos das pessoas individual ou institucionalmente consideradas, e o outro o de Vieira de Andrade, que, nas palavras de Jayme Weingartner:

(...) classifica os direitos fundamentais, quanto à titularidade, em quatro categorias: (a) direitos individuais; (b) direitos de exercício coletivo; (c) direitos de que também podem gozar as pessoas coletivas; (d) direitos coletivos estrito senso (direitos institucionais). Pensa que, a rigor, a individualidade (possibilidade de referência a homens individuais) é nota essencial do direito subjetivo fundamental, pois a dignidade humana só vale para as pessoas físicas - presente em (a) e (b). Na categoria (c) tem-se ainda direitos individuais, de que também podem gozar as

\footnotetext{
${ }^{38}$ MACHADO, Jónatas. Op. Cit. p. 235.

${ }^{39}$ Idem.
} 
pessoas coletivas (e.g. a liberdade de expressão, a liberdade de culto e de ensino religioso ou de criação de escolas). Apenas a categoria (d) agrupa os direitos exclusivos de pessoas coletivas ou organizações, vistos como verdadeiras competências. ${ }^{40}$

Hoje é um dado adquirido que, havendo um amplo reconhecimento da liberdade religiosa, deve-se reconhecer da mesma maneira a liberdade de associação e das associações religiosas. ${ }^{41}$ E desta forma entendeu a Constituição Federal, que, em seu artigo 19, inciso I, faz referência a "igrejas", no plural. Igualmente à Constituição Portuguesa, nossa Constituição não menciona uma única igreja, mas também não oferece definição. Essa palavra utilizada evidencia, mais uma vez, a influência histórica no presente tema, e como os discursos jurídico e teológico nem sempre surgem demarcados rigorosamente. Com relação à expressão "igreja", Jónatas Machado profere a seguinte explanação:

Ela situa-se no espaço discursivo teológico-confessional, assumindo aí, historicamente, um significado especificamente cristão, intimamente ligado, de resto, às controvérsias teológicas sobre qual seja a verdadeira Igreja. A sua consagração constitucional apresenta-se a reflectir cognitivamente o contexto histórico-cultural envolvente, densamente impregnado pela linguagem e pelos símbolos cristãos. ${ }^{42}$

Tendo em vista a igual dignidade e liberdade de todos os cidadãos, importa, aqui, alcançar um nível de generalidade conceitual que permita estender a proteção constitucional a todas as formas de interação social que tenham no fenômeno religioso o princípio e o fim da sua existência. É necessário limitar o máximo possível a intervenção jurisdicional, no sentido de que não é função do Estado determinar o que deva entender-se por confissão religiosa, igreja, ou outra expressão similar. Assim, são dignas de proteção não

\footnotetext{
${ }^{40}$ NETO, Jayme Weingartner. Op. Cit. p. 133.

${ }^{41}$ MACHADO, Jónatas. Op. Cit. p. 236.

${ }^{42}$ MACHADO, Jónatas. Op. Cit. p. 237.
} 
apenas as confissões antigas e tradicionais, fortemente institucionalizadas, com milhões de membros, de âmbito internacional, mas também todos os grupos que sustentem crenças religiosas em comum, que sejam "portadores de uma própria e original concepção do mundo", mesmo que dotados de uma organização interna incipiente. É preponderante, neste caso, o elemento associativo, o substrato pessoal que integra a confissão. ${ }^{43}$ Retenha-se que, conforme Jayme Weingartner:

(...) a intenção constitucional, vista numa interpretação sistemática, é captar uma vasta e diversificada fenomenologia - o poder constituinte quis afirmar um princípio de pluralismo confessional, mas não o soube exprimir senão através da ótica restrita do terreno judaico-cristão. ${ }^{44}$

O conceito "confissão religiosa", concebido em termos estritamente jurídicos, sem ligação a qualquer referência histórica ou teológica, parece ser preferível, densificado na "dupla valência associativa e institucional". Contudo, para melhor entendimento acerca de tal expressão, cabe citar a explanação de Jónatas Machado a respeito do seu sentido, invocando-se, assim, seu conteúdo histórico-teológico:

A expressão confissão religiosa (...) conhece sua origem na Reforma Protestante, quando a Cristandade dá lugar a várias confissões identificadas pela adesão a um conjunto de proposições de fé. No entanto, (...) com o Iluminismo ele começa a aplicar-se a todas as religiões, cristãs ou não, inclusive as mais antigas. A intenção do legislador constituinte ao utilizar esta expressão, juntamente com a de comunidade religiosa, foi a de encontrar uma linguagem suficientemente neutra e aberta que possibilitasse a construção do âmbito normativo do direito à liberdade religiosa em termos alargados e inclusivos, consentâneos com as finalidades constitucionais nesta matéria 45 .

Tal conceito, então, assente que não é legítimo impor ou privilegiar, por via legislativa ou hermenêutica, "uma determinada concepção ou estrutura

\footnotetext{
${ }^{43}$ Idem.

${ }^{44}$ NETO, Jayme Weingartner. Op. Cit. p. 135.

${ }^{45}$ MACHADO, Jónatas. Op. Cit. p. 237.
} 
organizatória em detrimento de outras", deve ser interpretado em termos que "precludam a sua identificação com as confissões tradicionais mais institucionalizadas e juridificadas". Frise-se que dentro de uma confissão religiosa pode haver divisões, isto é, diferentes comunidades religiosas, havendo múltiplas possibilidades de articulação entre elas, e, ainda, pode haver comunidades religiosas que não se consideram como confissão religiosa. ${ }^{46}$

Dentre todas as expressões que geram discussão quanto ao seu significado e à intenção do legislador - digam-se, igrejas, confissões religiosas, comunidades religiosas, etc -, Jayme Weingartner diz que o legislador português parece ter encontrado uma solução razoável para definir o termo também utilizado em nossa Constituição, "igrejas": "comunidades sociais organizadas e duradouras em que os crentes podem realizar todos os fins religiosos que lhes são propostos pela respectiva confissão" (artigo 20 da Lei da Liberdade Religiosa Portuguesa - LLR).

Não obstante, o que deve ficar claro é que todos os termos utilizados e as tentativas acima de explicar seus significados e intenção do legislador são unicamente para que seja demonstrado que a Constituição manifesta uma total disponibilidade para estender a sua proteção à multiplicidade organizatória que caracteriza a vivência coletiva da religião, e tratar com igual consideração e respeito as especificidades de cada grupo. ${ }^{47}$

Jónatas Machado menciona que boa parte da doutrina e jurisprudência constitucionais portuguesas, que tem abordado o presente assunto, tem frisado a particular autocompreensão e autodefinição doutrinária e institucional das comunidades religiosas, visando combater uma intervenção estatal, de tipo regalista, nos domínios da política eclesiástica. Diz o autor que este é o

\footnotetext{
${ }^{46}$ MACHADO, Jónatas. Op. Cit. p. 239.

${ }^{47}$ MACHADO, Jónatas. Op. Cit. p. 240. "Numa ordem constitucional integrada por cidadãos livres e iguais, não cabe ao Estado distinguir, em termos jurisdicionalistas e regalistas, entre a verdade e o erro, ou decidir quais são as boas ou as más confissões religiosas. (...) Não lhe compete promover a verdade, a Cristandade ou mesmo o diálogo ecumênico. Assim, em nome do princípio da igual liberdade, da
} 
objetivo primordial da liberdade religiosa coletiva, e que a este direito deve ser dada a máxima efetividade, devendo o seu exercício estar aberto a todos os grupos religiosamente comprometidos. ${ }^{48}$

\section{II.2. Direito geral de autodeterminação das confissões religiosas}

Como já visto, podem as confissões religiosas invocar, em iguais condições, o direito à liberdade religiosa, assim como podem os indivíduos. Nesta sede, o direito a uma igual liberdade religiosa, individual e coletiva, conflui com o princípio da separação das confissões religiosas do Estado, e tem como consequência o reconhecimento de um direito à autodeterminação das confissões religiosas, que se desdobra em liberdade de auto-organização das confissões e no direito de autodeterminação (estrito senso). A respeito desse assunto Jónatas Machado aduz:

Não se pretende disciplinar a religião em si mesma ou afirmar qualquer princípio geral de supremacia do poder político relativamente à autoridade religiosa, mas apenas acomodar o exercício da religião no contexto dos princípios básicos de uma ordem constitucional de reciprocidade, entendida como sistema justo de cooperação entre cidadãos livres e iguais. (...) o direito à liberdade religiosa colectiva deva ser exercido dentro dos limites impostos pela liberdade religiosa individual e pelos princípios da igualdade e da separação das confissões religiosas do Estado. ${ }^{49}$

\section{II.2.1. Liberdade de auto-organização}

Sobre o direito de liberdade religiosa coletiva referido na Constituição Portuguesa, Jónatas Machado diz que esta confere uma posição jurídica de liberdade na realização das atividades dos grupos religiosos, e isto é traduzido

neutralidade confessional do Estado e da separação das confissões religiosas do Estado, tais restrições, sejam elas feitas por lei, regulamento ou sentença judicial, são inapelavelmente inconstitucionais".

${ }^{48}$ Idem.

${ }^{49}$ MACHADO, Jónatas. Op. Cit. p. 241. 
da seguinte forma: (i) direito à abstenção de qualquer interferência pelo poder público; (ii) direito à proteção estatal perante terceiros, também convergindo a liberdade de associação (presente no artigo $5^{\circ}$, inciso XVII, da Constituição Federal de 1988), direito este que se consubstancia no próximo direito; (iii) direito à constituição de confissões e comunidades religiosas, com plena garantia de liberdade interna antes e independentemente da obtenção de personalidade jurídica, o que significa que a confissão não reconhecida como pessoa jurídica não pode deparar com restrições ao exercício à liberdade de culto. ${ }^{50}$ Ainda com relação ao ponto (iii), tem-se que mencionar que qualquer formação social de natureza religiosa pode contar com a proteção jurídica e estatal desde o seu surgimento, sem levar em conta a sua antiguidade ou a quantidade de aderentes, membros. Nesse sentido, Jónatas Machado faz uma alusão a um texto bíblico dizendo que "onde dois ou três estiverem reunidos em nome da religião, aí estará a protecção da liberdade religiosa colectiva". ${ }^{51}$

O artigo da Constituição Portuguesa ao qual refere-se Jónatas Machado encontra, na ideia de separação, similaridade com o artigo 19, inciso I, da nossa Constituição, que veda aos entes federados estabelecer cultos ou igrejas e subvencioná-los, bem como embaraçar-lhes o funcionamento, e manter relações de dependência/aliança. $\mathrm{O}$ direito genérico de liberdade de associação está inscrito, na Constituição Federal, no artigo $5^{\circ}$, inciso XVII, dispondo os incisos XVIII a XXI sobre a criação de associações e outros desdobramentos.

Frente à natural vocação que as comunidades religiosas possuem para a personificação jurídica, e à medida que esta seja um meio eficaz para a realização das suas próprias finalidades, pode-se dizer que se está aqui perante uma competência das comunidades religiosas, com o consequente direito à prestação estatal de normas que garantam e regulamentem seu exercício. Os

\footnotetext{
${ }^{50}$ MACHADO, Jónatas. Op. Cit. p. 241-242.

${ }^{51}$ MACHADO, Jónatas. Op. Cit. p. 244. Alusão feita às palavras de Jesus: "Porque, onde estiverem dois ou três reunidos em meu nome, aí estou eu no meio deles” (Mateus 18:20).
} 
requisitos fixados pela lei para o reconhecimento da personalidade jurídica a uma confissão religiosa, por sua vez, não podem pré-estabelecer um molde de forma arbitrária pelos poderes públicos. O único objetivo que devem ter é propiciar a maximização da liberdade religiosa de uma forma que cumpra com as exigências da ordem jurídica. Portanto, não é possível que tais requisitos subordinem o referido reconhecimento à observância de qualquer diretriz material sobre o conteúdo das proposições da fé. Acrescente-se que os requisitos a serem estabelecidos devem considerar "a necessidade de um mínimo de institucionalização compatível com as exigências da segurança jurídica e da proteção da confiança dos cidadãos, sendo ilegítimas quaisquer cláusulas que pretendam interferir no direito de auto-organização do grupo em causa". E o mais importante, a lei não deve ter uma consideração menor pelos grupos religiosos minoritários e, muito menos, "uma presunção no sentido do seu caráter fraudulento". ${ }^{52}$

Ao conferir-se personalidade jurídica às confissões religiosas, necessário é que sejam discutidas as consequências provenientes do estatuto de pessoa jurídica que elas irão se encaixar, no público ou no privado. Neste diapasão, Jayme Weingartner diz:

(...) as idéias de complementaridade e de relações de coordenação entre Estado e Igreja sustentam a compatibilidade da personalidade pública com os dados constitucionais de liberdade religiosa, o que exprimiria a autonomia e especificidade das confissões e o caráter originário de sua autoridade, sem significar assimilação da Igreja ao Estado ou sua subordinação à fiscalização. Em sentido contrário, fala-se de uma disfunção sistêmica, identificando-se um certo jus imperii com o financiamento da religião e consolidando privilégios e discriminações, pelo que a tendência contemporânea aponta para a igualdade entre as confissões religiosas e as demais pessoas jurídicas de direito privado, o que não limita suas 'aspirações de performance no espaço público', nem desvaloriza ou degrada a religião. ${ }^{53}$

\footnotetext{
${ }^{52}$ MACHADO, Jónatas. Op. Cit. p. 244.

${ }^{53}$ NETO, Jayme Weingartner. Op. Cit. p. 138.
} 
Considere-se que a personalidade de direito privado não retira das confissões sua autonomia funcional e normativa, enquanto que a opção pelo direito público só se mostra realmente cabível num estado confessional ou quase-confessional. Contudo, remeter as confissões religiosas ao regime geral do direito privado pode provocar um problema, que surge do fato de que, estando as confissões sujeitas às normas do Código Civil, podem chocar-se, muitas vezes, com a "estrutura associativa de base democrática programada no diploma civil, que se apóia em assembléia geral, órgão administrativo e conselho fiscal - o que em alguns casos pode violar a específica autocompreensão de alguma confissão religiosa". ${ }^{54}$

De toda forma, as confissões religiosas são enquadradas, no direito brasileiro, na categoria de pessoas jurídicas de direito privado, na modalidade de associações, nos termos do artigo 44, inciso I, do nosso Código Civil, que tem correspondência com o artigo 16, inciso I, do Código Civil de 1916, o qual dizia que "são pessoas jurídicas de direito privado as sociedades civis, religiosas, pias, morais, científicas ou literárias, as associações de utilidade pública e as fundações". Nesse sentido Aldir Guedes Soriano defende que as igrejas devem atuar como pessoas jurídicas, devendo seguir todo o iter previsto para a formação de uma pessoa jurídica de direito privado, e, ainda, da mesma forma como já explicitado:

Há liberdade para a formação de uma pessoa jurídica religiosa, conquanto se consubstancia em ato que expressa a vontade humana. Entretanto, há que se seguir os requisitos legais, por que a entidade possa existir como personalidade jurídica. Assim, é livre a organização religiosa na forma da lei, como determina a Constituição Federal (de um Estado Democrático de Direito). Essa organização depende, inclusive, da aprovação estatal, que, aliás, estimula a atividade religiosa com as imunidades tributárias. ${ }^{55}$

\footnotetext{
${ }_{55}^{54}$ NETO, Jayme Weingartner. Op. Cit. p. 138-139.

${ }^{55}$ SORIANO, Aldir Guedes. Liberdade religiosa no direito constitucional e internacional. São Paulo: Editora Juarez de Oliveira, 2002, p. 13.
} 


\section{II.2.2. Direito de autodeterminação}

É garantida às comunidades religiosas, pela Constituição, uma ampla medida de autonomia nas matérias circunscritas às suas próprias questões. Isto significa que é delimitado um "círculo vital", que é protegido através do reconhecimento de um "complexo de direitos de natureza negativa", os quais são expressões do princípio objetivo da neutralidade e não identificação estatal em matéria religiosa, e do reconhecimento da diversidade de fins das confissões e do Estado. Merecem destaque os direitos de autocompreensão, autodefinição, auto-organização, auto-administração, autojurisdição e autodissolução, que são reconduzíveis ao direito geral de autodeterminação. Tal direito deve ser exercido, logicamente, em conformidade com os princípios fundamentais, mais precisamente, com o valor básico da igual liberdade de todos os cidadãos. Jónatas Machado explana o direito de autodeterminação da seguinte forma:

De acordo com o direito de autodeterminação, todas as confissões religiosas, que não apenas as mais juridificadas ou institucionalizadas, devem ser consideradas como verdadeiras societae perfectae em matérias tão amplas e diversificadas como sejam, nomeadamente, a definição e interpretação dos princípios doutrinários do seu grau de vinculação, o exercício das funções de culto, a fixação dos pressupostos de admissibilidade de membros, a estrutura orgânica e funcional interna, a adopção de um modelo constitucional de tipo hierárquico, congregacional, etc. (...) Estas matérias integram uma verdadeira e própria reserva absoluta de confissão religiosa que funciona como norma definidora de competências negativas do Estado. ${ }^{56}$

Assim, conclui-se que respeitar a autonomia das confissões religiosas não significa realizar juízo de mérito sobre seu conteúdo teológico, "passando apenas pelo desdobramento do direito à liberdade religiosa num conjunto de posições jurídicas tuteladas pela concorrência e complementaridade dos diversos direitos, liberdades e garantias". Com isso, verifica-se que nessa margem de autonomia são vedadas todas as interferências dos poderes públicos

\footnotetext{
${ }^{56}$ MACHADO, Jónatas. Op. Cit. p. 247.
} 
de qualquer natureza (legislativa, administrativa, judicial). Como será visto no capítulo seguinte, as entidades religiosas resolverão seus conflitos doutrinários, organizatórios e funcionais sem ter que se submeter ao cumprimento de linhas estatais "pré-determinadas, mais ou menos uniformizadas ou estereotipadas". Necessário é que se frise, também, que qualquer pretensão das confissões religiosas de ultrapassarem os limites materiais e pessoais de sua autonomia, ultrapassa, igualmente, o âmbito de proteção do direito à liberdade religiosa. ${ }^{57}$

\section{II.3. Funções próprias / fins religiosos das confissões religiosas}

É certo que um dos fins do direito à liberdade religiosa é obter uma proteção jurídica da autonomia das diferentes confissões religiosas. Contudo, é evidente que essa proteção não tem em vista alcançar todas as atividades que elas concretamente desenvolvam, pois, caso assim ocorresse, haveria uma utilização abusiva desse direito fundamental. Isto ocorre porque as confissões e comunidades religiosas realizam não somente atividades religiosas propriamente ditas, mas também atividades instrumentais, apesar de estarem mais ou menos próximas da atuação religiosa. Desta maneira, cumpre distinguir, dentre as funções próprias das entidades religiosas, dois tipos de atividades: as não especificamente religiosas e as atividades institucionais, como, por exemplo, aquelas relações travadas entre as confissões e empresas comerciais. $^{58}$

O desafio que surge é o de precisar o que sejam "funções próprias" de modo compatível com um razoável controle estatal da sua plausibilidade. Para chegar à solução desse problema, Jónatas Machado fala de um modelo geométrico que apresentaria diferentes áreas definidas por um conjunto de círculos concêntricos de diferentes raios, representando as diversas atividades

\footnotetext{
${ }^{57}$ MACHADO, Jónatas. Op. Cit. p. 248.

${ }^{58}$ Idem.
} 
das confissões religiosas, em que a maior proximidade do centro traduz uma maior densidade religiosa dessas atividades. Então, percebe-se que atividades como o exercício, pelas pessoas jurídicas, de práticas cultuais, divulgação e propagação de conteúdos religiosos, ações de beneficência e assistência social gratuita, são casos em que o problema praticamente não se coloca, sendo certo a incidência da proteção da liberdade religiosa. ${ }^{59}$

A questão se torna mais complexa quando nos deparamos com atividades intimamente ligadas às finalidades de uma igreja, cuja realização, mesmo estando ausente qualquer intuito lucrativo, possui algum relevo econômico, envolve a participação no "tráfico jurídico"60. Como exemplos temos a criação de nova pessoa jurídica, a aquisição ou alienação de bens ou serviços, a prática de atos de comércio e de relações laborais, o recurso ao financiamento estatal, atividades de ensino e assistência hospitalar privados, exploração comercial de livros, discos, radiodifusão. Nestes casos será difícil defender que o direito de autonomia religiosa abrange todos os aspectos de desenvolvimentos dessas atividades, notando-se que as confissões podem invocar a liberdade religiosa para definir suas atividades, mas, importa ressaltar, que estão condicionadas, em linha de princípio, pela natureza jurídica das atividades que livremente escolheram, como pelas normas de natureza civil, comercial, administrativa, fiscal, etc. ${ }^{61}$ Isto ocorre ainda mais no caso de atividades que revestem-se de natureza comercial, embora ligadas ao financiamento das confissões religiosas. Portanto, evita-se o "enfraquecimento do âmbito normativo do direito à liberdade religiosa" e previne-se sua "utilização abusiva e simulada", de modo a não dar guarida a entidades

\footnotetext{
${ }^{59}$ Idem.

${ }^{60}$ MACHADO, Jónatas. Op. Cit. p. 250.

${ }^{61}$ MACHADO, Jónatas. Op. Cit. p. 250. Jónatas Machado cita um bom exemplo de González dell Valle para o melhor entendimento da questão, o qual diz que uma universidade batista ou um partido político católico estarão submetidos ao regime próprio das universidades e dos partidos políticos respectivamente. Deste modo, o fato de professar uma doutrina religiosa não muda a natureza da instituição que a professa.
} 
pseudo-religiosas $^{62}$ (igrejas de fachada), o que acaba por diminuir as probabilidades de discriminação estatal contra pessoas, naturais ou jurídicas, não religiosas. ${ }^{63}$

Seja como for, a verdadeira diferença entre as confissões religiosas e as demais entidades, públicas ou privadas, é o culto como atividade predominante das primeiras. Este é o critério para a identificação de uma confissão. Com efeito, as comunidades religiosas podem exercer outras atividades, que não sejam cultuais. Porém, sua atividade principal e preponderante é o culto. ${ }^{64}$

Nesse sentido, destaca-se uma recente questão em julgamento no Supremo Tribunal Federal, na qual se discute se templos maçônicos estão incluídos no conceito de "templos de qualquer culto" ou de "instituições de assistência social", como se verifica no artigo da Constituição que dispõe sobre imunidade tributária (artigo 150, VI, "b" e "c"). Sucede da seguinte forma o caso, conforme noticiado no Informativo n. ${ }^{\circ} 582$ do STF:

A Turma iniciou julgamento de recurso extraordinário em que se discute se templos maçônicos se incluem, ou não, no conceito de "templos de qualquer culto" ou de "instituições de assistência social" para fins de concessão da imunidade tributária prevista no art. 150, VI, b e c, da CF ["Sem prejuízo de outras garantias asseguradas ao contribuinte, é vedado à União, aos Estados, ao Distrito Federal e aos Municípios: ... VI - instituir impostos sobre: ... b) templos de qualquer culto; c) patrimônio, renda ou serviços dos partidos políticos, inclusive suas fundações, das entidades sindicais dos trabalhadores, das instituições de educação e de assistência social, sem fins lucrativos, atendidos os requisitos da lei;’]. No caso, alega a recorrente não poderem incidir impostos sobre imóveis que abrigam templos de qualquer culto ou sobre o patrimônio de entidades que pratiquem a assistência social, observados os requisitos da lei $\left(\mathrm{CTN}\right.$, art. 14 , I e II, e $\left.\S 2^{\circ}\right)$. Para isso, sustenta que - não obstante exista dentro da própria entidade controvérsia sobre o seu caráter religioso - poderse-ia dizer ser a maçonaria a religião das religiões, na medida em que, além de exigir de seus integrantes a crença em Deus, estimularia no maçom o desenvolvimento da religiosidade, incluindo-se, assim, no conceito de "templos

\footnotetext{
${ }^{62}$ Com relação a falsas entidades religiosas, Aldir Guedes Soriano explicita: "É comum o pensamento de que a organização religiosa não deve ser livre, sob o argumento de que muitos se aproveitam da fé, para se locupletarem. Apontam, ainda, como argumento, a existência de seitas perniciosas (...) Apesar de justificáveis, essas preocupações nada têm a ver com a liberdade de organização religiosa em sentido amplo, posto que não é absoluta. A existência de abusos não justifica a supressão, generalizada, dessa liberdade pública". (SORIANO, Aldir Guedes. Op. Cit p. 14-15.).

${ }^{63}$ MACHADO, Jónatas. Op. Cit. p. 250.

${ }^{64}$ MACHADO, Jónatas. Op. Cit. p. 251.
} 
de qualquer culto" para os fins do art. 150, VI, b, da CF. Argumenta, também, enquadrar-se na hipótese do art. 150, VI, c, da CF, dado que seria uma instituição nitidamente com caráter filantrópico.

Quanto ao disposto no art. 150, VI, b, da CF, o Min. Ricardo Lewandowski negou provimento ao recurso. Inicialmente, observou que a questão central do recurso estaria em saber se a referência a "templos de qualquer culto" alcançaria, ou não, a maçonaria. Aduziu que o art. $5^{\circ}$, VI, da CF seria expresso em assegurar o livre exercício dos cultos religiosos e que uma das formas que o Estado estabelecera para não criar embaraços à prática religiosa fora outorgar imunidade aos templos onde se realizem os respectivos cultos. Enfatizou que, no caso, a interpretação do referido dispositivo deveria ser restritiva, atendendo às razões de sua cogitação original. Consignou, no ponto, que as liberdades deveriam ser interpretadas de forma extensiva, não devendo o Estado criar qualquer óbice à manifestação de consciência, porém, deveria ser dado tratamento diametralmente oposto, ou seja, restritivo às imunidades. Nessa linha, asseverou que, quando a Constituição confere imunidade tributária aos "templos de qualquer culto", este benefício fiscal estaria circunscrito aos cultos religiosos. Registrou, ademais, que a própria entidade, em seu estatuto, declarara enfaticamente não ser uma religião e, por tal razão, pareceria irretocável a decisão a quo. No que tange ao art. 150, VI, c, da CF, não conheceu do extraordinário, dado que o cumprimento dos requisitos previstos no art. 14 do CTN constituiria conditio sine qua non para o gozo da imunidade tributária outorgada pela $\mathrm{CF}$, sendo inevitável, destarte, o revolvimento do conjunto fático-probatório (Enunciado da Súmula 279 do STF: "Para simples reexame de prova não cabe recurso extraordinário"). Após os votos dos Ministros Dias Toffoli, Cármen Lúcia e Ayres Britto, que acompanhavam o voto do relator, pediu vista dos autos o Min. Marco Aurélio. RE 562351/RS, rel. Min. Ricardo Lewandowski, 13.4.2010. (RE$562351)^{65}$ (grifou-se)

Verifica-se, portanto, que o ponto fundamental consiste no fato de haver controvérsia dentro da própria entidade sobre seu caráter religioso, pois alguns entendem que a maçonaria não é religião, e assim declara o estatuto da própria entidade, embora o recorrente alegue que a maçonaria é a "religião das religiões". Desta forma, vale destacar que, conforme já visto no primeiro subitem deste capítulo, a proteção dada pela Constituição às confissões religiosas deve ser estendida à multiplicidade organizatória que caracteriza a vivência coletiva da religião, e levar em consideração as especificidades de cada grupo, pois, além de poder haver divisões entre as próprias confissões, pode haver aquelas que não se considerem confissão religiosas, o que não

${ }^{65}$ Art. 150, VI, b e c, da CF: Maçonaria e Imunidade Tributária - 1 e 2. Informativo n. ${ }^{\circ} 582$ do STF. 
significa que não sejam. Ressalte-se que não é função do Estado definir o que é confissão religiosa.

Normalmente, se conceitua a maçonaria como uma associação. Porém, como já exposto, as entidades religiosas podem possuir outras atividades além do culto religioso, desde que este seja sua função primordial. O culto, portanto, é o que diferencia as confissões religiosas das demais, e não o fato dela se autodeterminar religião ou não. Desta maneira, apenas com o intuito de possibilitar uma maior reflexão acerca do tema, destaca-se o seguinte trecho a respeito da maçonaria, retirado do site de uma loja maçônica:

A Maçonaria não é uma religião no sentido de ser uma seita, mas é um culto que une homens de bons costumes. A Maçonaria não promove nenhum dogma que deve ser aceito taticamente por todos, mas inculca nos homens a prática da virtude, não oferecendo panacéias para a redenção de pecados. Seu credo religioso consiste apenas em dois artigos de fé que não foram inventados por homens, mas que se encontram neles instintivamente desde os mais remotos tempos da história: A existência de Deus e a Imortalidade da Alma que tem como corolário a Irmandade dos Homens sob a Paternidade de Deus. ${ }^{66}$

\section{II.4. Invocação ao direito à liberdade religiosa por outras pessoas jurídicas}

Uma outra questão interessante é a que versa sobre a possibilidade de outras pessoas jurídicas, que não as confissões religiosas, invocarem a proteção do direito à liberdade religiosa. Não se está falando aqui daquela pessoa jurídica neutra, que nada tem a ver com religião ou causa religiosa alguma, mas daquela que tenha "como elemento estruturalmente caracterizador um vínculo com a prossecução de interesses ou finalidades de natureza religiosa”. Ressalte-se que as pessoas jurídicas de direito público interno estão afastadas de imediato (artigo 41, do Código Civil, combinado com o artigo 19, inciso I, da Constituição Federal), diga-se, a União, os Estados, o Distrito Federal, os

\footnotetext{
${ }^{66}$ Conheça a maçonaria. Disponível em <www.lojasaopaulo43.com.br> Acesso em 20/05/2010.
} 
Municípios, etc, pois, se assim não fosse, se estaria diante de uma violação frontal ao princípio da separação das confissões religiosas do Estado. Já no plano do direito privado, nada impede que "interesses religiosos, globais ou parcelares, estejam na base da constituição de associações, ainda que estas não se compreendam como confissões religiosas ou como vinculadas a confissões religiosas". 67

No caso de fundações (artigo 44, inciso III, do Código Civil) também não parece existir problema, porque, ainda que a afetação patrimonial realce o relevo estrutural na prossecução das finalidades do fundador, a "liberdade religiosa compreende a faculdade de estabelecer fundações em que o fim se reveste de um caráter religioso". A invocação do direito à liberdade religiosa, neste último caso, "é corolário da liberdade religiosa do fundador", que pode ser pessoa física ou jurídica. ${ }^{68}$

\footnotetext{
${ }^{67}$ Idem.

${ }^{68}$ MACHADO, Jónatas. Op. Cit. p. 252.
} 


\section{Capítulo III}

\section{A INGERÊNCIA DO ESTADO NO SEIO DAS CONFISSÕES RELIGIOSAS}

\section{III.1. A vinculação das pessoas jurídicas pelo direito à liberdade religiosa}

O direito à liberdade religiosa é um direito subjetivo público pelo fato de ser acionável por iniciativa dos seus titulares diante do Poder Público. Conforme já foi visto nos capítulos anteriores, o Estado deve garantir o exercício, sem perturbações, do direito à liberdade religiosa através de prestações positivas e negativas. Isto quer dizer, em apertada síntese, que deve ser exigida a necessária atenção e contenção por parte do Poder Público, e que o mesmo deve assegurar a permanência de um espaço para o desenvolvimento adequado de todas as confissões religiosas, "empreendendo esforços e zelando para que haja essa condição estrutural propícia ao desenvolvimento pluralístico das convicções pessoais sobre religião e fé". ${ }^{69}$ Assim, é certo que os indivíduos devem exigir do Estado a proteção ao direito à liberdade religiosa, e, da mesma forma, os mesmos possuem os direitos, liberdades e garantias, como direitos de defesa contra o Estado. Portanto, não apenas o direito à liberdade religiosa, mas todos os direitos fundamentais constituem os fundamentos da ordem jurídica estatal e devem ser observados em todas as atividades do Poder Público.

Deste modo, é clara a vinculação dos direitos fundamentais ao Estado. Entretanto, é importante sublinhar que tal vinculação não é limitada

\footnotetext{
${ }^{69}$ TAVARES, André Ramos. Religião e neutralidade do Estado. In: SORIANO, Aldir; MAZZUOLI, Valério (Org.). Direito à liberdade religiosa: desafios e perspectivas para o século XXI. Belo Horizonte: Editora Fórum, 2009. p. 56.
} 
unicamente ao Poder Público, como se apenas este pudesse ameaçar ou violar o exercício de tais direitos. Ao contrário, ela é dirigida à totalidade dos indivíduos e das forças integrantes da comunidade que representam as múltiplas relações disciplinadas pelo direito privado. Com isso, verifica-se o efeito erga omnes dos direitos fundamentais, pois os titulares destes direitos podem valer-se da tutela constitucional que lhes é dispensada contra quem quer que os viole. Isto permite que se conclua pela forte ligação entre a vinculação das entidades privadas e públicas, pois, para que a primeira ocorra, é preciso que "os órgãos estatais protejam, concretizem e maximizem os direitos fundamentais quando, diante de problemas colocados nas relações entre particulares, são chamados a criar, interpretar e aplicar normas jurídicas". ${ }^{70}$

$\mathrm{O}$ artigo $18^{\circ}, \mathrm{n}^{\circ}$ 1, da Constituição Portuguesa, estende a vinculação dos direitos, liberdades e garantias às entidades privadas, sendo estas vistas como corresponsáveis na realização de direitos fundamentais. No direito brasileiro, a discussão é balizada a partir do $\S 1^{\circ}$ do artigo $5^{\circ}$ da Constituição Federal (as normas definidoras de direitos e garantias fundamentais têm aplicação imediata). Sobre isto, cabe mencionar o aduzido por Pontes de Miranda, que diz que as regras jurídicas sobre os direitos fundamentais somente estão plenamente asseguradas se todos os cidadãos e os outros particulares as respeitam, e não somente as entidades estatais. ${ }^{71}$

No caso específico da liberdade religiosa, Jónatas Machado fala sobre a necessidade de se alcançar "soluções materiais diferenciadas" em face de situações de substancial desigualdade na distribuição de poder entre os particulares, ou de vulneração intolerável de esferas constitucionalmente

\footnotetext{
${ }^{70}$ MACHADO, Jónatas. Liberdade religiosa numa comunidade constitucional inclusiva: Dos direitos da verdade aos direitos dos cidadãos. Coimbra: Coimbra Editora, 1996. p. 254.

${ }^{71}$ MIRANDA, Pontes de. Comentários à Constituição de 1967. Tomo IV. São Paulo: RT, 1967. p. 118.
} 
protegidas de intimidade pessoal. Constata-se a abordagem diferenciada na comparação feita pelo mesmo autor:

(...) se um banco apresenta nos seus quadros dirigentes um número significativamente mais baixo de mulheres, relativamente à média normal no sector da intermediação financeira, é legítimo presumir que se está perante uma discriminação sexual ilícita à face do princípio constitucional da igualdade, devendo os poderes públicos tomar as medidas legislativas, administrativas e judiciais adequadas e necessárias para a combater. Diferentemente se passam as coisas, quando é uma confissão religiosa a proceder a esse tipo de discriminação, na medida em que a mesma resulte da sua particular autocompreensão e autodefinição doutrinária. Qualquer medida estadual no sentido de obrigar a confissão religiosa a não discriminar pode pôr em causa o direito à liberdade religiosa colectiva, na sua dimensão de liberdade de seleccionar os membros e os dirigentes da confissão, para além de ameaçar a própria identidade do grupo religioso enquanto tal. ${ }^{72}$

Percebe-se, portanto, a importância de tratar-se da vinculação ao direito à liberdade religiosa pelas entidades privadas, uma vez que as confissões religiosas são pessoas jurídicas, e, assim, além de titulares desse direito, são também destinatárias do mesmo. ${ }^{73}$

\section{III.2. O princípio da tolerância}

O princípio da tolerância é visto como um princípio complementar ao direito à liberdade religiosa, e é entendido como dever de respeito pela dignidade e personalidade alheias, da mesma forma como pelas diferentes crenças e opções de consciência. Trata-se de uma "atitude de respeito e boa-fé que os cidadãos e grupos de cidadãos devem ter uns para com os outros numa sociedade pluralista regulada por uma ordem constitucional de justiça, reciprocidade e igual liberdade" 74 , que terá grande importância em casos como

\footnotetext{
${ }^{72}$ MACHADO, Jónatas. Op. Cit. p. 255.

${ }^{73}$ Tratando desse assunto, Jónatas Machado aborda não somente a questão da liberdade religiosa no seio das confissões religiosas, como também no seio da família e nas relações laborais. Contudo, o presente trabalho se restringirá ao estudo da primeira questão.

${ }^{74}$ MACHADO, Jónatas. Op. Cit. p. 256.
} 
o de reuniões públicas de natureza religiosa ou de divulgação de mensagens religiosas. Na verdade, esta é uma virtude cívica, na qual pensamentos liberais e republicanos se cruzam, e a tolerância passa a ser um princípio conformador do direito fundamental à liberdade religiosa, a vincular as relações entre particulares, servindo de critério auxiliar para a resolução de conflitos entre direitos fundamentais.

Ao Estado é incumbida a função institucional de "guardião da tolerância", devendo tomar as medidas necessárias para criar e proteger o desejado clima de respeito mútuo. Nesse sentido, discorre Humberto Martins que "o Estado tem que fomentar, através das leis e de campanhas institucionais, o respeito à diversidade religiosa, que, no Brasil, é uma derivação imediata do princípio da dignidade humana e um fundamento da República, sob a forma do pluralismo religioso". ${ }^{75}$ Passando para o plano subjetivo, o autor prossegue:

(...) a tolerância perpassa a aceitação das diferenças religiosas; o acatamento das formas de culto; o respeito ao proselitismo; a coibição do proselitismo abusivo, como o emprego de formas de pregação que ultrapassem os limites da liberdade individual, da intimidade, da privacidade e da autodeterminação.

Desta forma, observa-se que o dever de tolerância, que incide nas relações entre particulares e o Estado, influencia os direitos de autocompreensão e audefinição, de auto-organização e de auto-administração, a liberdade de professar a própria crença, o direito de se informar sobre religião, de participar de comemorações públicas e de reuniões, manifestações e associações religiosas, além do direito de proselitismo, isto é, divulgar o próprio credo e promover as próprias expressões culturais, e utilizar os meios de comunicação social.

\footnotetext{
${ }^{75}$ MARTINS, Humberto. Liberdade religiosa e Estado Democrático de Direito. In: SORIANO, Aldir; MAZZUOLI, Valério (Org.). Direito à liberdade religiosa: desafios e perspectivas para o século XXI. Belo Horizonte: Editora Fórum, 2009. p. 109.
} 


\section{III.3. Direitos fundamentais e intervenção estatal}

As confissões religiosas podem ser examinadas sob o ângulo de potenciais agressoras dos direitos dos indivíduos, sendo colocado aqui o problema da vinculação das entidades religiosas pelos direitos fundamentais, o que torna de grande importância e necessidade a indagação do sentido e limites das mesmas, assim como a possibilidade de intervenção do Estado frente a tais instituições.

Para que se dimensione melhor a complexidade dos problemas decorrentes do presente tema, vale apontar certas questões utilizadas como exemplo por Jónatas Machado: seria possível reintegrar-se ao corpo docente de um seminário professor afastado por suas posições heterodoxas em questões sensíveis (aborto, contracepção, homossexualidade) ou por defender ponto de vista ateu? Qual o alcance da liberdade de expressão no âmbito das confissões religiosas? Seria possível uma mulher alegar ter sido vítima de discriminação sexual diante da recusa das autoridades eclesiásticas à sua pretensão de abraçar o sacerdócio? E o caso de uma mulher solteira, professora de escola de ensino confessional, que é despedida por motivo de gravidez? ${ }^{76}$ E se tal mulher fosse, em vez de professora, mera funcionária administrativa (situação em que não poderia ser alegado o mau exemplo para os alunos do ponto de vista pedagógico-religioso)? ${ }^{77}$

Essas questões, entre outras, demonstram o problema da vinculação das entidades religiosas pelos direitos, liberdades e garantias. Para facilitar uma resposta a tais perguntas, deve-se acoimar que as confissões religiosas, conforme cita Jónatas Machado, "podem não ser do mundo mas estão no mundo, movimentando-se no âmbito da ordem constitucional livre e

\footnotetext{
${ }^{76}$ Neste caso, é certo que se deve observar, igualmente, o disposto na legislação trabalhista.

${ }^{77}$ MACHADO, Jónatas. Op. Cit. p. 270.
} 
democrática". Deste modo, deve-se encontrar um equilíbrio, evitando-se tanto a excessiva fiscalização do Estado, que poderia coibir o pleno exercício do direito à liberdade religiosa, quanto a criação de um princípio de imunidade espiritual das mesmas. Há que se considerar, assim, tanto a proteção do direito à liberdade religiosa dos indivíduos, quanto o das confissões religiosas, ambos com seus limites e restrições. Além disso, é preciso que se leve em conta que a jurisdição estatal, no âmbito confessional, dialoga com os princípios da separação e da não confessionalidade, e com o direito de autodeterminação das confissões. Assim, as confissões protagonizam, ao mesmo tempo, papéis de titulares e destinatários dos direitos fundamentais. ${ }^{78}$

Desta feita, verificando-se que as confissões religiosas são vinculadas aos direitos fundamentais, observa-se, também, que tal fato cria uma colisão de direitos, estando de um lado o direito de autodeterminação das confissões, e de outro os direitos dos indivíduos. Isto ocorre no cenário de uma unidade hierárquico-normativa da Constituição, na qual cada direito fundamental possui como limite a igual dignidade de tutela jurídica dos demais direitos fundamentais, sendo requerida, como forma de se vencer tal colisão, uma tarefa de concordância prática orientada pela preocupação de não deixar desprovido de tutela qualquer direito. ${ }^{79}$

Para se tentar alcançar uma harmonização entre o direito de autodeterminação das confissões e os demais direitos dos indivíduos, cumpre salientar que a liberdade religiosa das primeiras deve ser exercida "no quadro de uma ordem jurídica edificada sobre os valores da dignidade da pessoa humana e da igual liberdade de todos os cidadãos". Desta forma, é necessário observar os indivíduos como aderentes e não-aderentes à confissão, para assim se verificar a influência desta sobre aqueles, sabendo-se que no caso dos nãoaderentes, isto é, aqueles que não se colocaram voluntariamente sob a

\footnotetext{
${ }^{78}$ MACHADO, Jónatas. Op. Cit. p. 272.

${ }^{79}$ Idem.
} 
jurisdição moral ou espiritual de uma entidade religiosa, não é possível que a entidade faça uso de quaisquer poderes sobre os mesmos. Caso isto acontecesse, ou seja, se aqueles que não aderiram aos ditames de uma determinada confissão fossem obrigados a cumprir suas regras de conduta, a essência do direito à liberdade religiosa seria indiscutivelmente violada, pois, em uma sociedade aberta e pluralista, na qual há a separação entre Estado e religião, a tutela dos direitos dos não aderentes se torna um limite intransponível ao direito à autodeterminação das confissões religiosas. ${ }^{80}$

Com relação àqueles que voluntariamente aderiram à crença religiosa, pode-se dizer que aceitaram submeter-se a um conjunto de normas geralmente aceitas como indisponíveis, uma vez que foram impostas por uma autoridade sobrenatural. Importa ressaltar que isto não atenta em nada contra a liberdade religiosa, pois o indivíduo possui o direito de abandonar a confissão religiosa a qualquer momento. Todavia, ao aderir a uma confissão, o indivíduo se depara com uma "entidade orgânica irredutível a uma mera agregação dos seus aderentes", que possui identidade, valores, princípios e regras específicos, aos quais o "membro" deve obedecer. Deste modo, como se pode perceber, a condição para permanecer na confissão religiosa é adotar uma conduta compatível com os seus preceitos e aceitar as suas decisões. Aqui, portanto, se faz perceptível o choque entre o direito individual e a liberdade coletiva de autocompreensão e autodeterminação doutrinária e institucional. Jónatas Machado diz que esses direitos constituem o fórum internum das confissões religiosas à medida que manifestam a sua "especificidade ontológica e estrutural". Esse fórum internum é um domínio reservado e protegido de interferências estatais, pois, se assim não fosse, não haveria "sentido útil ao direito à liberdade colectiva". 81

\footnotetext{
${ }^{80}$ Idem.

${ }^{81}$ MACHADO, Jónatas. Op. Cit. p. 273.
} 
Sendo assim, vê-se a impossibilidade de intervenção estatal frente a casos de conflito entre aderentes e confissão religiosa, o qual tenha cunho exclusivamente doutrinário. Como exemplificado por Jónatas Machado, hipóteses nas quais o membro se coloca em contradição quanto à doutrina e à prática que a confissão prega, ou quanto à decisão proferida por autoridade confessional contra si, não comportam a intervenção do Estado. Assim, o aderente não pode esperar uma tutela estatal contra tal decisão ou pretender um pronunciamento de um tribunal comum sobre a justiça ou correção doutrinal da mesma. Além disso, a confissão religiosa também é autorizada a aplicar, da maneira que bem entender, sanções de natureza estritamente confessional, sem que se possa invocar a sua vinculação aos direitos, liberdades e garantias. $\mathrm{O}$ autor oferece, neste contexto, outra situação comum de ocorrer no âmbito das confissões religiosas:

[o] indivíduo, pelo cargo que desempenha, ou pela função que exerce no seio da confissão religiosa, se coloca, do ponto de vista desta última, numa posição em que, pelas suas convicções ou conduta moral, deixa de se identificar pessoalmente com as suas finalidades e pode obstruir a realização eficaz de sua missão religiosa. ${ }^{82}$

Neste caso, da mesma forma como assinalado acima, a confissão religiosa pode tomar as atitudes doutrinárias que achar necessárias. Ademais, em casos de descumprimento de deveres de lealdade e de conduta suscetíveis a afetar e desacreditar a imagem moral da confissão religiosa, as autoridades confessionais podem executar suas ações relativas aos seus fiéis mesmo quando se verifique a existência de vínculo empregatício, pois, além de zelar por sua imagem, as confissões são livres para escolher as pessoas mais adequadas à realização das suas finalidades. Este é "um elemento central do direito de autonomia religiosa colectiva". ${ }^{83}$

\footnotetext{
${ }^{82}$ Idem.

${ }^{83}$ MACHADO, Jónatas. Op. Cit. p. 274.
} 
Neste diapasão, Humberto Martins aduz acerca do princípio da separação institucional desenvolvido pelo Direito Constitucional moderno, princípio este cujo conteúdo expressa a distinção jurídico-política dos organismos religiosos e o Estado. Através desse princípio decorre-se que "não é permitido ao Estado interferir na nomeação ou no afastamento de líderes religiosos", e que "a organização interna das igrejas e comunidades religiosas é infensa ao controle político, doutrinário ou econômico do Estado". ${ }^{84}$

No Brasil, em conformidade com o artigo $5^{\circ}$, inciso XXXV, da Constituição Federal, o cidadão pode recorrer ao Judiciário em face de eventual lesão ou ameaça ao direito à liberdade religiosa. Acerca dessa possibilidade de litígio envolvendo o direito à liberdade religiosa, assinala Aldir Guedes Soriano que "litígios podem ser estabelecidos entre os indivíduos (cidadãos), entre o cidadão e o Estado, entre o cidadão e as organizações religiosas e, também, entre as organizações religiosas (confissões religiosas) e o Estado". ${ }^{85}$ Como o próprio autor aduz, as contendas entre as confissões religiosas e o Estado estão relacionadas, normalmente, a questões de autonomia eclesiástica ou estatal.

Um exemplo real do assunto aqui esposado é a decisão judicial que, mediante liminar, determinou a realização de casamento religioso de uma noiva grávida, mesmo estando $\mathrm{o}$ ato em total desconformidade às normas eclesiásticas de determinada denominação evangélica. Esse caso foi noticiado da seguinte maneira:

O juiz Sérgio Mendonça de Araújo, da $12^{a}$ Vara Cível de Goiânia, concedeu liminar, no dia 23 de abril, determinando a realização da cerimônia de casamento de Ú. L. A. A. e P. H. O. A. no templo da $1^{\text {a }}$ Igreja Batista. Em seu pedido, a noiva destacou que,

\footnotetext{
${ }^{84}$ MARTINS, Humberto. Liberdade religiosa e Estado democrático de Direito. In: SORIANO, Aldir; MAZZUOLI, Valério (Org.). Direito à liberdade religiosa: desafios e perspectivas para o século XXI. Belo Horizonte: Editora Fórum, 2009. p. 108.

${ }^{85}$ SORIANO, Aldir Guedes. Direito à liberdade religiosa sob a perspectiva da democracia liberal. In: SORIANO, Aldir; MAZZUOLI, Valério (Org.). Direito à liberdade religiosa: desafios e perspectivas para o século XXI. Belo Horizonte: Editora Fórum, 2009. p. 167.
} 
apesar de ter sido batizada na igreja, foi comunicada pelos pastores de que não poderia celebrar o matrimônio no local, por estar grávida.

O casal argumentou que estavam habilitados ao casamento perante o Cartório de Registro Civil e de Pessoas Naturais e Tabelionato de Notas da $4^{\text {a }}$ Circunscrição. A noiva afirmou também que estava sofrendo enorme sofrimento e prejuízos de ordem material decorrentes de despesas com a realização da cerimônia.

Segundo o magistrado, o gesto da $1^{\text {a }}$ Igreja Batista fere a Constituição e o Código Civil, que estão acima dos dogmas religiosos. Concedida a liminar, os oficiais de justiça tiveram dificuldade para intimar os pastores da igreja. No feriado, o juiz plantonista Rodrigo de Silveira determinou a abertura das portas do templo religioso pelos oficiais de justiça.

Pedido negado antes

O pedido havia sido negado, no dia 18 , pelo juiz Jaime Rosa Borges, da $4^{\text {a }}$ Vara de Família e Sucessões de Goiânia. O casal ajuizou ação cautelar inominada contra a $1^{\text {a }}$ Igreja Batista de Goiânia para que fosse realizado o casamento no templo. Ao negar o primeiro pedido, o juiz Jaime Rosa ponderou que não existe na lei civil disposição que obrigue a autoridade ou ministro religioso a celebrar o casamento, de forma "que o ato fica na dependência da relação de conveniência entre os contraentes e a autoridade eclesiástica". $O$ juiz explicou que quem não pode negar-se à celebração do matrimônio é a autoridade civil que dela for encarregada. $O$ juiz disse que se a $1^{\text {a }}$ Igreja Batista de Goiânia tem motivo para não celebrar o casamento, e considerando que tal motivo decorre de regras comportamentais moralmente ditadas pela religião as quais está submetida, o Poder Judiciário não pode determinar a realização do ato, sob pena de interferência ilegal nas relações privadas dos particulares. ${ }^{86}$ (grifou-se)

Essa decisão incorre em grave violação ao direito à liberdade religiosa garantido às confissões religiosas, ferindo, também, os seus direitos à autodeterminação e autodefinição doutrinária. No caso concreto, os noivos eram, claramente, membros da igreja, tendo aderido livremente à crença e, assim, submetidos às suas doutrinas e seus preceitos. A partir do momento em que passaram a não mais concordar com as regras da igreja, os autores tinham todo o direito de abandonar sua crença, mas não esperar que o Estado interviesse na questão, o que, de maneira totalmente errada, ocorreu. A igreja, nesse caso, poderia até ser condenada ao pagamento de indenização por danos materiais aos noivos, mas nunca poderia ser obrigada a realizar a cerimônia religiosa. Como corretamente afirmou o juiz Jaime Rosa, o Poder Judiciário não pode determinar a realização da cerimônia, pois o motivo que levou o

\footnotetext{
${ }^{86}$ Juiz obriga igreja a fazer casamento. Disponível em <www.jusbrasil.com.br $>$ (extraído de Expresso da notícia). Acesso em 06/05/2010.
} 
pastor a negar o feito decorre de "regras comportamentais moralmente ditadas pela religião", regras estas às quais os noivos estavam submetidos. Ao contrário do que aduziu o juiz que determinou a realização do casamento, o gesto da igreja não fere a Constituição e o Código Civil. Contudo, a decisão de tal magistrado, sim, viola o direito à liberdade religiosa assegurado pela Carta da República.

Nesse contexto, vale destacar o artigo $5^{\circ}$, inciso VIII, da Carta Magna, e indagar se ele pode gerar alguma implicação no âmbito interno das religiões. O referido artigo diz que "ninguém será privado de direitos por motivo de crença religiosa ou de convicção filosófica ou política, salvo se as invocar para eximir-se de obrigação legal a todos imposta e recusar-se a cumprir prestação alternativa, fixada em lei”. Pode-se afirmar que esse dispositivo, ao assegurar que ninguém será privado de direitos por motivo de crença religiosa, não se refere às questões internas das confissões e não possui o condão de impedir que determinada religião imponha restrições a certos direitos como condição para que um cidadão integre aquela confissão religiosa. Entretanto, existe quem entenda o contrário, como a Procuradora de Justiça de São Paulo, Luiza Nagib Eluf, que, em artigo publicado no jornal Folha de São Paulo, defendeu que o artigo $5^{\circ}$, VIII, da Constituição Federal, poderia ser invocado pelas muçulmanas que não quisessem usar o véu islâmico. Assim, a Procuradora de Justiça entende que "o dispositivo, criado para evitar discriminações em razão de credo, é de ser aplicado, também, para evitar violações de direitos trazidas pelas próprias religiões aos seus seguidores". ${ }^{87}$ Todavia, tal entendimento está equivocado, pois não é possível que se invoque o mencionado artigo constitucional para afastar determinado preceito da confissão. Referente a esse assunto, Fábio Carvalho Leite cita como exemplo o fato de um cidadão que quisesse ser padre. Este não poderia invocar o mencionado artigo

\footnotetext{
${ }^{87}$ ELUF, Luiza Nagib. O véu religioso. Folha de São Paulo, São Paulo, p. A3, 30 dezembro 2003.
} 
constitucional para afastar a exigência do celibato, condição que é imposta pela Igreja Católica a todos que desejam exercer o sacerdócio. ${ }^{88}$

Entende-se, portanto, que a não-intervenção do Estado no corpo das confissões religiosas faz parte do direito de liberdade religiosa de que as mesmas também gozam. Contudo, consideração similar vale para casos em que o próprio conteúdo doutrinal das confissões sustenta crenças segregacionistas e comportamentos discriminatórios em relação a determinadas classes de pessoas identificadas pelo sexo, raça, etc? Nestes casos, nas palavras de Jónatas Machado, “o Estado não pode impor os seus próprios critérios normativos, proibindo, por exemplo, a discriminação de mulheres ou de indivíduos de uma certa raça no acesso ao sacerdócio".

Nesse sentido, pode-se destacar outro caso real que aborda a questão da discriminação no âmbito das confissões religiosas. Tal caso ocorreu no Reino Unido, quando um Bispo Anglicano de Hereford foi processado judicialmente por não ter contratado para trabalhar com a juventude da igreja um homossexual praticante. O cidadão alegou ter sido discriminado devido à sua orientação sexual, enquanto que o bispo afirmou que o motivo dele não ter sido contratado se deveu ao fato de ter assumido praticar relações sexuais, e não por ser homossexual. O bispo se defendeu dizendo que a igreja agiu da mesma maneira como teria agido com qualquer pessoa que tivesse praticado relações sexuais fora do casamento, independentemente de sua orientação sexual. ${ }^{89}$ Todavia, isto nos leva a indagar: poderia uma igreja recusar, para um cargo interno, alguém que tivesse cometido adultério ou fornicação, atos tidos como pecado na doutrina eclesiástica, mas não poderia fazer o mesmo com um homossexual, ato igualmente considerado pecaminoso? Ambas as situações dizem respeito aos direitos de autodeterminação, autocompreensão e

\footnotetext{
${ }^{88}$ LEITE, Fábio Carvalho. Estado e religião no Brasil: A liberdade religiosa na Constituição de 1998. Rio de Janeiro. 2008. Tese (Doutorado em Direito). Departamento de Direito da UERJ.

89 Gay man's lifestyle made him unfit for post, insists bishop. Disponível em <www.timesonline.co.uk>. Acesso em 10/05/2010.
} 
autodefinição das igrejas. Estas possuem a liberdade de escolher as pessoas com o "perfil mais adequado à promoção das suas doutrinas e à realização da sua missão religiosa", e, como já verificado acima, tal liberdade de escolha faz parte da autonomia religiosa coletiva. ${ }^{90}$

É certo que o direito à liberdade religiosa proíbe todas as formas possíveis de intolerância estatal, mas em seu programa normativo não se verifica qualquer direito de resistência do indivíduo contra quaisquer expressões de discriminação ou intolerância dogmática de origem confessional. A essa luz, cumpre transcrever o entendimento de Jayme Weingartner, que assevera:

Neste ponto, gostaria de reforçar a idéia de que o fundamentalismo hermenêutico tem que ser tolerado pelo Estado, ao provir das confissões religiosas, contra as quais não há direito individual de resistência à intolerância, salvo se, resvalando para o fundamentalismo militante, pretendam atingir, coercitivamente, não-aderentes. ${ }^{91}$

Neste domínio, o autor continua no sentido de que há duas ordens de ideias que se combinam no âmbito dessa questão:

Por um lado, o princípio da tolerância atinge o Estado e os indivíduos, não porém as igrejas, que se beneficiam dos princípios da separação e da não-confessionalidade e de uma posição preferencial da garantia institucional da autodeterminação confessional. Por outro, o indivíduo que adere voluntariamente a uma confissão submete-se aos dogmas e práticas da igreja respectiva; se não for aderente, tais dogmas e práticas das igrejas não lhe podem ser impostos. ${ }^{92}$

Essa "ausência de direito subjetivo de resistência contra a intolerância dogmática confessional" pode gerar alguma discussão quando se está falando de entidades como igrejas e outras comunidades religiosas, ou seja, de "pendor indiscutivelmente religioso", que são financiadas exclusivamente pelos seus

\footnotetext{
90 MACHADO, Jónatas. Tempestade perfeita? Hostilidade à liberdade religiosa no pensamento teorético-jurídico. In: SORIANO, Aldir; MAZZUOLI, Valério (Org.). Direito à liberdade religiosa: desafios e perspectivas para o século XXI. Belo Horizonte: Editora Fórum, 2009. p. 149.

${ }^{91}$ NETO, Jayme Weingartner. Op. Cit. p. 246.

${ }^{92}$ Idem.
} 
próprios recursos. Entretanto, a situação torna-se ainda mais complicada quando há cooperação entre as confissões e o Estado, como no caso de estabelecimentos de ensino ou instituições de solidariedade social nos quais ocorre tal relação de cooperação e uma convergência de elementos religiosos e estatais, que são traduzidos na presença de finalidades religiosas de natureza pedagógica ou assistencial, e na prossecução de tarefas do Poder Público, mediante o fornecimento de prestações fáticas. Assim, a questão está em como atingir um equilíbrio, já que o direito geral de autodeterminação e o direito de livre exercício de atividades não-religiosas das igrejas colidem com os princípios da cooperação e da solidariedade. ${ }^{93}$

Com o fim de tratar dessa questão, a doutrina norte-americana oscila entre duas orientações, quais sejam a doutrina da ação estatal (state action doctrine) e a doutrina das condições inconstitucionais (unconstitutional conditions). A primeira possui o escopo de evitar que o Estado venha a sancionar ou consolidar práticas discriminatórias das entidades privadas. Sustenta boa parte dessa doutrina a subordinação das prestações positivas do Estado à aceitação, por parte das mesmas, da conformidade com os princípios constitucionais fundamentais, estando vedado ao Estado subvencionar atividades, públicas ou privadas, que atentem contra tais princípios. Deste modo, é mais intenso o grau de vinculação das confissões religiosas aos direitos fundamentais se forem financiadas pelo dinheiro público, devendo ser evitada a "proliferação de estruturas de segregação e discriminação" sob pena de não ter direito a qualquer subvenção estatal. No sentido inverso está a segunda doutrina, que subordina a obtenção de quaisquer subvenções estatais à renúncia, por parte da entidade beneficiária, ao exercício de um direito constitucionalmente consagrado. Para esta tese, com vistas às isenções fiscais e concessões de subvenções, o Estado não pode deixar de beneficiar, em condições de igualdade, todas as entidades religiosas constitucionalmente

\footnotetext{
${ }^{93}$ MACHADO, Jónatas. Op. Cit. p. 276.
} 
aceitas, ou seja, que não promovam a violência e que estejam de acordo com a lei penal, independentemente do seu conteúdo possuir concepções discriminatórias, pois, do contrário, as confissões religiosas estariam no dilema de exercer um direito constitucionalmente consagrado ou obter uma subvenção estatal, que significaria ter que renunciar o exercício desse direito, além de permitir que o Estado afirme sua competência para decidir quais são as confissões religiosas "socialmente respeitáveis" ou quais podem ou não "violar o princípio da igualdade". 94

Com relação a tais doutrinas, Jónatas Machado expressa que, em seu entender, a última posição merece uma maior aceitação, pois leva mais longe a proteção do direito à liberdade religiosa. No entanto, não descarta completamente a primeira orientação, acrescentando alguns comentários:

(...) devem ter-se como inadmissíveis subvenções a confissões contrárias à ordem pública constitucional, mesmo que esta seja entendida, como deve ser, em termos abertos e inclusivos. Acresce que as confissões religiosas competem no mercado de ideias não apenas umas com as outras, mas também com outros grupos sociais de natureza política, social, cultural, filosófica e ideológica, não podendo a concessão de subvenções a instituições de matriz confessional abstrair do efeito de distorção que daí pode resultar para a livre circulação de idéias. ${ }^{95}$

Desta maneira, o Estado possui o dever de proteger a liberdade e o pluralismo no espaço público, buscando evitar que a discriminação de procedência confessional acabe por legitimar e consolidar a discriminação no plano político e jurídico. Assim, verifica-se que cabe ao Estado salvaguardar os direitos e os interesses legítimos dos indivíduos, e também os bens constitucionais da comunidade, o que justifica uma ingerência sua de natureza legislativa, administrativa e judicial. Com isso, fica clara a vinculação das confissões religiosas pelos direitos, liberdades e garantias, embora em seu campo interno essa vinculação seja abrandada.

\footnotetext{
${ }^{94}$ Idem.

${ }^{95}$ MACHADO, Jónatas. Op. Cit. p. 277.
} 


\section{III.4. Limites do direito à liberdade religiosa}

Diante do todo exposto no tópico anterior, é preciso abordar a questão dos limites do direito à liberdade religiosa, pois, caso contrário, poderia-se pensar que se está defendendo aqui uma superproteção a esse direito fundamental, e que sob ele tudo poderia ser praticado, principalmente no caso das confissões religiosas, o que não é verdade. Deve-se sublinhar, primeiramente, que os direitos fundamentais podem ser restringidos por expressa disposição constitucional ou mediante lei ordinária com fundamento na própria Constituição, além do uso da ponderação e da concordância prática, havendo algumas restrições explícitas no texto constitucional, as quais decorrem do regime excepcional de estado de necessidade. No caso particular da liberdade religiosa, não há previsão explícita, no plano constitucional, de qualquer restrição legal. Devido à sua íntima relação com o princípio da dignidade da pessoa humana, o direito à liberdade religiosa é construído com um perímetro alargado. Contudo, isso não significa que esse direito não possua limitação alguma.

É importante frisar que nos aspectos em que a liberdade religiosa se desdobra em posições jurídicas compreendidas em outros direitos fundamentais, como a liberdade de expressão, reunião, associação, etc., ela encontra alguns limites constitucionais, pois lhe são aplicáveis àqueles que valem genericamente para esses outros direitos fundamentais. A respeito dos direitos fundamentais, Alexandre de Moraes salienta:

Os direitos humanos fundamentais não podem ser utilizados como um verdadeiro escudo protetivo da prática de atividades ilícitas, nem tampouco como argumento para afastamento ou diminuição da responsabilidade civil ou penal por atos criminosos, sob pena de total consagração ao desrespeito a um verdadeiro Estado de Direito.(...) Os direitos e garantias fundamentais consagrados pela Constituição 
Federal, portanto, não são ilimitados, uma vez que encontram seus limites nos demais direitos igualmente consagrados pela Carta Magna. ${ }^{96}$

Desta forma, a liberdade religiosa, como os demais direitos do homem, não pode servir de escudo protetivo para dar guarida a atividades ilícitas ou atos que atentem contra a ordem pública, a moral e os bons costumes. Vale destacar, como já foi dito no primeiro capítulo, que nas constituições de 1946 e 1967 estava expresso que a liberdade religiosa deveria ser compatível com a ordem pública e os bons costumes. Com isso, pode-se dizer que a maioria dos autores brasileiros, como Pontes de Miranda, Alexandre de Moraes, Manoel Gonçalves Ferreira Filho, Aldir Soriano, entre outros, entendem que, embora as expressões "ordem pública" e "bons costumes" não estejam presentes na Constituição de 1988, a liberdade religiosa deve ser assegurada quando não contrária a elas.

Nesse sentido, frisamos, também, que as práticas decorrentes do direito à liberdade religiosa devem respeitar as leis penais, isto é, não podem ser tais que constituam crimes ou contravenções, não lhes sendo permitido, igualmente, infringir outras liberdades. Nesse contexto, Jónatas Machado ensina:

\begin{abstract}
Assim, é vedada a utilização do direito à liberdade de reunião e associação religiosa para justificar a prossecução de fins violentos (...) ou à lei penal (...), ou, ainda, para contrariar a aplicabilidade de outras regras constitucionais que condicionem, de alguma forma, o exercício desses direitos (...). Quanto ao mais, só se poderá falar na existência de limites implícitos, resultantes de uma leitura sinóptica dos preceitos constitucionais e da necessidade lógico-sistemática de compatibilização substancial, a posteriori, do direito em causa com os direitos de terceiros, e com outros bens jurídicos (vida, integridade física, saúde, ambiente, qualidade de vida) constitucionalmente protegidos. ${ }^{97}$
\end{abstract}

\footnotetext{
${ }^{96}$ MORAES, Alexandre de. Direitos humanos fundamentais. $2^{a}$ ed. São Paulo: Atlas, 1998. p. 46.

${ }^{97}$ MACHADO, Jónatas. Op. Cit. p. 281-282.
} 


\section{III.5. Desafios atuais à liberdade religiosa}

Apesar da afirmação da liberdade religiosa e do seu corolário de separação das confissões religiosas do Estado nas inúmeras constituições e tratados internacionais, não vem ocorrendo a uniformização da disciplina jurídica desse direito. Seria até possível pensar que a universalização da liberdade religiosa a coloca numa posição inatacável. Porém, como assevera Jónatas Machado, isto se trata apenas de "uma segurança aparente e enganadora", pois a liberdade religiosa tem enfrentado críticas das mais diversas procedências. Muitas estão inseridas, inclusive, numa abrangente tentativa de desconstruir os direitos fundamentais e humanos. Diante desse cenário, será abordado, a seguir, uma questão que, com a bandeira de combate à discriminação sexual, fere o direito à liberdade religiosa. Fala-se de uma das algumas correntes que têm se formado, nas quais predomina uma "generalizada desconfiança em face do discurso religioso, realidade que, no futuro, pode confrontar a liberdade religiosa com importantes desafios". ${ }^{98}$

\section{III.5.1. Teoria jurídica homossexual}

As religiões mais tradicionais, de maior preponderância e influência mundialmente, como o Cristianismo, o Islamismo e o Judaismo, possuem como discurso religioso a doutrina da criação, considerada revelada e, portanto, indisponível. Disto decorre, nas palavras de Jónatas Machado, "uma específica compreensão moral do ser humano, das diferenças biológicas e psicológicas entre homens e mulheres, da complementaridade dos gêneros, do matrimônio, da sexualidade, da procriação, da família, etc". A partir dessa

\footnotetext{
98 MACHADO, Jónatas. Tempestade perfeita? Hostilidade à liberdade religiosa no pensamento teorético-jurídico. In: SORIANO, Aldir; MAZZUOLI, Valério (Org.). Direito à liberdade religiosa: desafios e perspectivas para o século XXI. Belo Horizonte: Editora Fórum, 2009. p. 118.
} 
compreensão moral surgem implicações sociais, que decorrem do pensamento de que tanto o Estado, como a sociedade, não podem ocupar uma posição neutra em relação a tal compreensão, mas que devem tomar uma posição diante disso. ${ }^{99}$

Cumpre salientar que a referida compreensão moral baseada na doutrina da criação teve uma influência imensurável e profunda em grandes conquistas da humanidade, nos quadrantes culturais e geográficos, além do desenvolvimento dos direitos humanos no ocidente, que sempre teve "como pano de fundo o desenvolvimento de premissas culturais dotadas de um escoramento ético religioso". A doutrina da criação coloca em lugar de destaque a questão familiar, da onde se insurge uma organização social baseada na família. Demonstrando os resultados advindos desse discurso religioso predominante até os dias de hoje, Jónatas Machado aduz:

A questão social da disciplina jurídica da unidade familiar está longe de ser indiferente ao discurso religioso, observando-se que este se desenvolve, geralmente, em torno de temas como o matrimônio de indivíduos de sexo oposto, a consideração da paternidade de ambos os progenitores como modelo sócio-ecológico óptimo, a harmonização e disciplina do desejo heterossexual e do seu poder generativo, uma preocupação com o desenvolvimento pessoal e social equilibrado das crianças e a transmissão intergeracional de valores essenciais para a vida individual e colectiva. ${ }^{100}$

Tendo em vista o conteúdo do discurso da criação, verifica-se que um assunto muito em pauta ultimamente, o homossexualismo, é considerado um desvio à ordem da criação, tendo sua causa nos efeitos espirituais, morais e físicos provenientes da queda do homem, isto é, do pecado. Em decorrência desse entendimento, surgem algumas teorias críticas do direito, que consideram que a religião e a heteronormatividade não passam de um "repositório de preconceitos arcaicos". Nesse sentido, surge o movimento

\footnotetext{
${ }^{99}$ MACHADO, Jónatas. Tempestade perfeita? Hostilidade à liberdade religiosa no pensamento teorético-jurídico. Op. Cit. p. 144.

${ }^{100}$ MACHADO, Jónatas. Tempestade perfeita? Hostilidade à liberdade religiosa no pensamento teorético-jurídico. Op. Cit. p. 145.
} 
teorético-jurídico "gay and lesbian legal studies”, que, como Jónatas Machado explica:

Pode ser compreendido como um ramo das teorias críticas do direito, tendo em comum com elas a teorização a partir de uma perspectiva desconstrutiva de outsider, da qual decorre naturalmente a negação da objectividade do direito, o radicalismo esquerdista da crítica dirigida aos valores tradicionais e a adopção do slogan de que o direito é política e, na maior parte dos casos, política de direita. ${ }^{101}$

Para esse movimento, a compreensão moral que domina a sociedade deve ser substituída por um desenvolvimento social centrado numa cultura de relacionamentos, entendendo o casamento como um instituto totalmente desvinculado da questão de gênero ou da orientação sexual, mas fundado simplesmente nos valores da amizade, do companheirismo, da intimidade, da confiança, da gratificação sexual e do compromisso. Além disso, esse movimento teorético-jurídico defende que todo o direito, incluindo-se os direitos fundamentais, como a liberdade religiosa, deve passar por uma reinterpretação que leve em conta o objetivo político-constitucional da eliminação das categorias e dos estereótipos tradicionais de diferenciação e hierarquização da orientação sexual. Tais direitos devem, portanto, assumir-se como "construções sociais auto-subsistentes, funcionais, dinâmicas e inclusivas". ${ }^{102}$

Tal perspectiva teórica pode até ser sedutora e parecer demonstrar um empenho em lutar a favor de uma sociedade sem preconceitos. Todavia, a mesma representa uma ameaça ao direito à liberdade religiosa ao atacar e desconsiderar liminarmente qualquer argumentação religiosa, e ver na religião a sede, por excelência, do preconceito homofóbico, procurando subverter todo

\footnotetext{
${ }^{101}$ MACHADO, Jónatas. Tempestade perfeita? Hostilidade à liberdade religiosa no pensamento teorético-jurídico. Op. Cit. p. 146.

${ }^{102}$ MACHADO, Jónatas. Tempestade perfeita? Hostilidade à liberdade religiosa no pensamento teorético-jurídico. Op. Cit. p. 147.
} 
entendimento religioso, a não ser o daquelas confissões que têm se colocado ao lado de seus defensores.

O discurso do "gay and lesbian legal studies" procura impor seus próprios critérios de autonomia e homonormatividade para, em seguida, avaliar a religião com base neles. Isto ocorre ao mesmo tempo em que recusa que qualquer critério religioso possa vir avaliar a sua compreensão de autonomia e homonormatividade. Como se pode ver, essa orientação ideológica está longe de possuir ideais neutros do ponto de vista mundividencial e indiferentes do ponto de vista da estruturação da sociedade, pois tende a excluir qualquer entendimento diverso do seu, defendendo a exclusão, por uma razão pública secularizada, de "qualquer referência genérica a uma ordem natural que sublinhe a natureza fundacional da união heterossexual na construção da humanidade e da sociedade". ${ }^{103}$ É de extrema relevância ressaltar que uma exclusão de tal porte, como os defensores do movimento em referência alimentam, pode trazer grandes e perigosas transformações no âmbito da sociedade, tendo como consequência o modo de conceber a família, a sexualidade, a procriação e a educação. Como Martin Rhonheimer assinala, mesmo cidadãos homossexuais devem reconhecer que a união matrimonial heterossexual é a razão da existência da sociedade, e que eles mesmos devem a sua existência a ela. Portanto, a união heterossexual possui uma relevância política que a união de mesmo sexo não dispõe. ${ }^{104}$

Deste modo, o referido movimento põe em risco o direito à liberdade religiosa na medida em que é uma porta de entrada para uma versão mais radical dessa corrente, que pode vir a ser "visceralmente hostil à promoção de ideias religiosas e das inevitáveis implicações daí resultantes para discussão de temas como a família, a sexualidade, o gênero, a orientação sexual, a procriação, etc". Por isso, o "gay and lesbian legal studies" pode acabar por

\footnotetext{
${ }^{103}$ Idem.

${ }^{104}$ Idem.
} 
criar uma estratégia de marginalização e silenciamento dos argumentos religiosos, e ainda obstar as práticas das religiões a respeito desse assunto, mobilizando o sistema jurídico para atingir esse objetivo, de uma maneira que venha a comprometer as dimensões essenciais da autocompreensão doutrinal das confissões religiosas.

Com isso, verifica-se que todo o acima exposto ameaça o direito à liberdade religiosa gozado também pelas confissões religiosas, pois, como já visto, viola o direito de autocompreensão, como também o de autodefinição doutrinal, os quais fazem parte do conteúdo essencial do seu direito de liberdade religiosa. Nesse sentido, Jónatas Machado assevera:

Uma tentativa de limitar o discurso ontológico das confissões religiosas em domínios como a vida, o ser humano, a sexualidade, os géneros e a orientação sexual não deixaria de significar uma grave intromissão no modo com as confissões religiosas procuram gerir a sua relação com o que consideram ser verdade revelada. ${ }^{105}$

Além disso, limitar os preceitos defendidos pelas religiões seria o mesmo que eliminar o papel de salvaguarda dos indivíduos perante a tentativa do Estado de "padronizar a sociedade de acordo com critérios politicamente corretos", papel esse desempenhado pelas confissões religiosas. ${ }^{106}$

Um exemplo concreto acerca de tal ameaça ao direito à liberdade religiosa é o projeto de lei n. ${ }^{\circ}$ 5.003/2001 da Câmara dos Deputados (PLC n. ${ }^{\circ}$ 122/2006 do Senado Federal), que foi aprovado pela primeira e está para ser votado no Senado Federal. Esse projeto define os crimes resultantes de discriminação ou preconceito de gênero, sexo, orientação sexual e identidade de gênero, alterando o Código Penal e a Consolidação das Leis do Trabalho. Através dele é demonstrado como o movimento homossexual busca mobilizar o sistema jurídico para alcançar suas finalidades, comprometendo o direito de

\footnotetext{
${ }^{105}$ MACHADO, Jónatas. Tempestade perfeita? Hostilidade à liberdade religiosa no pensamento teorético-jurídico. Op. Cit. p. 149.

${ }^{106}$ Idem.
} 
autocompreensão doutrinal das religiões, conforme é percebido através do artigo 20 da referida lei, que assim dispõe:

Art. 20. Praticar, induzir ou incitar a discriminação ou preconceito de raça, cor, etnia, religião, procedência nacional, gênero, sexo, orientação sexual e identidade de gênero.

$\S 5^{\circ} \mathrm{O}$ disposto neste artigo envolve a prática de qualquer tipo de ação violenta, constrangedora, intimidatória ou vexatória, de ordem moral, ética, filosófica ou psicológica;

Verifica-se, através da leitura desse dispositivo, que a manifestação ou expressão de inconformidade "de ordem moral, ética, filosófica ou psicológica" é equiparada à "ação violenta, constrangedora, intimidatória ou vexatória”, o que significa a proibição, não apenas de algum tipo de ação discriminatória, mas também a simples expressão de discordância com alguma orientação sexual. Isto intervém claramente no âmbito interno das confissões religiosas, que, sendo aprovada tal projeto de lei, não poderão mais pregar e expressar sua doutrina, ou, ainda, serão obrigadas a aceitar determinadas situações sob pena de estarem cometendo um crime. Assim, uma igreja, por exemplo, não poderia se negar a contratar uma pessoa, para trabalhar em suas dependências, devido à sua orientação sexual ou se negar a batizar um homoafetivo, mesmo que tal ato infrinja sua doutrina e conceitos.

Desta forma, o projeto de lei . $^{\circ} 5.003 / 2001$ demonstra como a teoria jurídica homossexual incentiva a intervenção abusiva do Estado no âmbito das religiões, proibindo que estas expressem suas doutrinas. Deve-se relembrar, aqui, que as confissões religiosas apenas exigem que suas regras sejam cumpridas aos seus aderentes, e, a partir do momento em que alguém não concorde mais com tais regras pode abandonar a religião quando quiser. Portanto, as confissões não podem exigir ou tentar impor algum de seus pensamentos a qualquer pessoa que não seja membro ou aderente. Reitere-se, contudo, que aos seus membros as entidades religiosas estão asseguradas pelo 
direito à liberdade religiosa a pregar sua doutrina e, com base nela, tomar as decisões que acharem mais corretas e adequadas. 


\section{CONCLUSÃO}

O presente trabalho teve o intuito de tratar do direito à liberdade religiosa titulado pelas confissões religiosas, um assunto não muito abordado pela doutrina brasileira, mas que tem começado a aparecer. Verificamos que esse direito tem sido ameaçado sob forma de lei, de movimentos em prol de outros direitos, como é percebido através do movimento "gay and lesbian legal studies" e da elaboração do projeto de lei n. ${ }^{\circ}$ 5.003/2001, que já foi aprovado na Câmara dos Deputados, estando pendente de votação pelo Senado Federal. Percebe-se que está faltando equilíbrio, ponderação entre os princípios, que uns querem reivindicar certos direitos suprimindo outros.

É certo que o direito à liberdade religiosa coletiva não tem o fim de permitir toda e qualquer prática das confissões religiosas, funcionando como um escudo protetor contra a fiscalização e intervenção do Estado, atrás do qual tudo pode ser realizado, não importando se direitos são violados. Ela visa proteger, sim, as confissões de fiscalização e intervenção abusiva por parte do Estado, mas também impõe limites às condutas das religiões. No que tange à intervenção do Estado nas confissões, conforme o pensamento de John Rawls, o mesmo não pode restringir o livre exercício religioso em face de seus próprios interesses. Aliás, existindo uma colisão de valores, os direitos fundamentais devem prevalecer diante do interesse estatal. Assim, o referido direito garante os direitos de autocompreensão, autodeterminação e autodefinição das igrejas, o que significa que elas são livres para determinar seu conteúdo doutrinal e agir nas questões internas, nomeando líderes, aceitando e excluindo membros, contratando empregados, entre outras atividades. Tais atividades são rotineiras para as diversas religiões e expressa sua liberdade religiosa. Um membro insatisfeito com alguma de suas atitudes não pode esperar uma atuação do Estado que venha a comprometer o exercício de tal direito, devendo simplesmente abandonar aquela confissão religiosa. 
Além disso, deve-se acautelar acerca dos diversos movimentos e pensamentos que ameaçam a liberdade religiosa. Como já citado, existem diversas correntes de pensamento que nascem todos os dias e vêm para hostilizar o fenômeno religioso, vendo-o de forma unilateral, reducionista, como realidade irracional e impedimento à promoção dos direitos fundamentais, como contribuintes para divisão, e que defendem a sua marginalização, privatização e superação. Tais correntes, como abordado no presente estudo, a teoria jurídica homossexual, entre outras, como o republicanismo laicista, o liberalismo político, a ética comunicativa, o comunitarismo, procuram incentivar o Poder Legislativo a elaborar leis que venham suprimir o direito constitucional à liberdade religiosa, sob o disfarce, na maioria das vezes, de defensores de direitos não reconhecidos, de promotores dos direitos fundamentais do homem.

O curioso é que tais correntes desconsideram o fato de que ao ignorar o fenômeno religioso, ou melhor, suprimi-lo, estão atuando contra um direito constitucionalmente protegido e internacionalmente reconhecido, isto é, um direito humano. Assim, não se pretendeu, neste trabalho, gerar discussões acerca do fenômeno religioso, mas da liberdade religiosa. Contudo, o que ocorre é que não é possível falar sobre liberdade religiosa sem tratar desse fenômeno.

Deste modo, é necessário que o presente tema seja mais discutido com o fim de impedir que movimentos e correntes venham por em risco o direito à liberdade religiosa, bem como obstar investidas do Poder Público de restringir o exercício a esse direito constitucional que é gozado pelas confissões religiosas. Isto deve ocorrer através de uma concepção de liberdade religiosa que leve a sério a consciência individual e as convicções e práticas religiosas, sem comprometer os princípios do Estado de direito. 


\section{BIBLIOGRAFIA}

Art. 150, VI, b e c, da CF: Maçonaria e Imunidade Tributária - 1 e 2. Informativo $\mathrm{n}{ }^{\circ} 582$ do STF.

BLANCARTE, Roberto. O porquê de um Estado laico. In: LOREA, Roberto Arriada (Org.). Em defesa das liberdades laicas. Porto Alegre: Editora Livraria do Advogado, 2008.

Conheça a maçonaria. Disponível em <www.lojasaopaulo43.com.br> Acesso em 20/05/2010.

COSTA, Maria Emília Corrêa da. Apontamentos sobre a liberdade religiosa e a formação do Estado laico. In: LOREA, Roberto Arriada (Org.). Em defesa das liberdades laicas. Porto Alegre: Editora Livraria do Advogado, 2008.

ELUF, Luiza Nagib. O véu religioso. Folha de São Paulo, São Paulo, p. A3, 30 dezembro 2003.

Gay man's lifestyle made him unfit for post, insists bishop. Disponível em <www.timesonline.co.uk>. Acesso em 10/05/2010.

Juiz obriga igreja a fazer casamento. Disponível em <www.jusbrasil.com.br> (extraído de Expresso da notícia). Acesso em 06/05/2010.

LEITE, Fábio Carvalho. Estado e religião no Brasil: A liberdade religiosa na Constituição de 1998. Rio de Janeiro. 2008. Tese (Doutorado em Direito). Departamento de Direito da UERJ.

MACHADO, Jónatas. Liberdade religiosa numa comunidade constitucional inclusiva: Dos direitos da verdade aos direitos dos cidadãos. Coimbra: Coimbra Editora, 1996.

MACHADO, Jónatas. Tempestade perfeita? Hostilidade à liberdade religiosa no pensamento teorético-jurídico. In: SORIANO, Aldir; MAZZUOLI, Valério (Org.). Direito à liberdade religiosa: desafios e perspectivas para o século XXI. Belo Horizonte: Editora Fórum, 2009.

MARTINS, Humberto. Liberdade religiosa e estado democrático de direito. In: SORIANO, Aldir; MAZZUOLI, Valério (Org.). Direito à liberdade religiosa: desafios e perspectivas para o século XXI. Belo Horizonte: Editora Fórum, 2009. 
MIRANDA, Pontes de. Comentários à Constituição de 1967. Tomo II. São Paulo: RT, 1967.

MIRANDA, Pontes de. Comentários à Constituição de 1967. Tomo IV. São Paulo: RT, 1967.

MORAES, Alexandre de. Direitos humanos fundamentais. $2^{a}$ ed. São Paulo: Atlas, 1998.

NETO, Jayme Weingartner. Liberdade religiosa na Constituição: fundamentalismo, pluralismo, crenças, cultos. Porto Alegre: Livraria do advogado editora, 2007.

SARMENTO, Daniel. O porquê de um Estado laico. In: LOREA, Roberto Arriada (Org.). Em defesa das liberdades laicas. Porto Alegre: Editora Livraria do Advogado, 2008.

SILVA, José Afonso da. Curso de Direito Constitucional Positivo. $27^{\mathrm{a}}$ ed. São Paulo: Malheiros editores, 2006.

SORIANO, Aldir Guedes. Direito à liberdade religiosa sob a perspectiva da democracia liberal. In: SORIANO, Aldir; MAZZUOLI, Valério (Org.). Direito à liberdade religiosa: desafios e perspectivas para o século XXI. Belo Horizonte: Editora Fórum, 2009.

SORIANO, Aldir Guedes. Liberdade religiosa no Direito constitucional e Internacional. $1^{\mathrm{a}}$ ed. São Paulo: Editora Juarez de Oliveira, 2002.

STERNICK, Daniel. O conceito de laicidade no Estado judeu: controvérsias em torno da liberdade religiosa em Israel. In: LEITE, Fábio (Org.). Cadernos do Departamento de Direito da Pontifícia Universidade Católica do Rio de Janeiro. Rio de Janeiro: Editora PUC-RIO, 2010.

TAVARES, André Ramos. Religião e neutralidade do Estado. In: SORIANO, Aldir; MAZZUOLI, Valério (Org.). Direito à liberdade religiosa: desafios e perspectivas para o século XXI. Belo Horizonte: Editora Fórum, 2009. 


\section{ANEXO I}

\section{Reportagem retirada do site www.timesonline.com.uk}

\section{Gay man's lifestyle made him unfit for post, insists bishop}

A gay man was rejected for a post as a youth worker because of his sexual lifestyle, not his sexual orientation, a Church of England bishop told an employment tribunal yesterday.

The Right Rev Anthony Priddis, the Bishop of Hereford, said that John Reaney did not get the job because he had admitted having had sex outside marriage.

The Bishop denied unlawfully discriminating against Mr Reaney, saying that he had been complying with the teachings of the Church.

He said that he told Mr Reaney that any person in a sexual relationship outside marriage, whether they were heterosexual, homosexual, bisexual or transgender, would have been rejected for the post.

"Such sexuality in itself was not an issue, but Mr Reaney's lifestyle had the potential to impact on the spiritual, moral and ethical leadership within the diocese," he said yesterday.

He added that his views on sex outside marriage were backed by the Archbishop of Canterbury, the General Synod, the national assembly of the Church of England, and the Lambeth Conference.

Mr Reaney, 41, from Llandud-no, North Wales, claims that being openly gay cost him the job. His claim for unlawful discrimination against the Hereford Diocesan Board of Finance is being backed by the gay rights group Stonewall.

Under equality legislation introduced in 2003, it is illegal to discriminate against people because of their sexual orientation, although 
organised religions were given exemptions. The hearing is believed to be the first test case of how it applies to the Church of England.

The tribunal in Cardiff was told that Mr Reaney had been offered the job last July after an interview before a panel of eight. The Bishop, 59, was told that he had indicated on his form that he was homosexual.

Mr Reaney was called in for a discussion, during which it emerged that he had recently ended a five-year homosexual relationship.

The Bishop said that, although Mr Reaney undertook not to start a new gay relationship, he felt that he was not emotionally in a position to be making such a promise.

He told the tribunal: "The end of a five-year relationship leads to a lot of grieving and it can take much time for someone to recover. It would not have been right for me to take an undertaking of his head that his heart could not keep. It remains my judgment that Mr Reaney had not met the standards required. It was not a risk I was prepared to take."

He said that Mr Reaney did not seem overwrought, humiliated or distressed when he was told that his application was being turned down.

The tribunal was told that the job was not offered to anyone else. Bishop Priddis said that, because of the diocese's limited finances, even if Mr Reaney had been appointed he might have been made redundant "sooner rather than later".

The Bishop denied that he had breached the diocese's equal opportunities policy. He said: "The Church's teaching draws distinction between sexual orientation and practice and lifestyle. We didn't discriminate against Mr Reaney on the grounds of sexuality. Had we done so we wouldn't have called him for an interview.

"What is at issue is the lifestyle, practice and sexual behaviour, whether the applicant is homosexual, heterosexual or transsexual." 
The Bishop added that his diocese had ordained a transsexual woman as a priest. In September 2005 Sarah Jones, who was a man for 29 years, was described by Bishop Priddis as a "superb candidate" for the post.

The hearing continues. 


\section{ANEXO II}

PROJETO DE LEI No 5.003-B, DE 2001

Altera a Lei $n^{\circ} 7.716$, de 5 de janeiro de
1989 , que define os crimes resultantes de
preconceito de raça ou de cor, dá nova
redação ao $\S 3^{\circ}$ do art. 140 do Decreto-Lei $n^{\circ}$
2.848 , de 7 de dezembro de 1940 - Código
Penal, e ao art. $5^{\circ}$ da Consolidação das Leis
do Trabalho, aprovada pelo Decreto-Lei $n^{\circ}$
5.452 , de $1^{\circ}$ de maio de 1943 , e dá outras
providências.

O CONGRESSO NACIONAL decreta:

Art. $1^{\circ}$ Esta Lei altera a Lei $\mathrm{n}^{\circ} 7.716$, de 5 de janeiro de 1989 , o Decreto-Lei $\mathrm{n}^{\circ}$ 2.848, de 7 de dezembro de 1940 - Código Penal, e a Consolidação das Leis do Trabalho, aprovada pelo Decreto-Lei $n^{\circ} 5.452$, de $1^{\circ}$ de maio de 1943, definindo os crimes resultantes de discriminação ou preconceito de gênero, sexo, orientação sexual e identidade de gênero.

Art. $2^{\circ}$ A ementa da Lei $n^{\circ} 7.716$, de 5 de janeiro de 1989, passa a vigorar com a seguinte redação:

"Define os crimes resultantes de discriminação ou preconceito de raça, cor, etnia, religião, procedência nacional, gênero, sexo, orientação sexual e identidade de gênero."(NR)

Art. $3^{\circ} \mathrm{O}$ caput do art. $1^{\circ}$ da Lei $\mathrm{n}^{\circ} 7.716$, de 5 de janeiro de 1989 , passa a vigorar com a seguinte redação:

"Art. $1^{\circ}$ Serão punidos, na forma desta Lei, os crimes resultantes de discriminação ou preconceito de raça, cor, etnia, religião, procedência nacional, gênero, sexo, orientação sexual e identidade de gênero."(NR)

Art. $4^{\circ}$ A Lei ${ }^{\circ} 7.716$, de 5 de janeiro de 1989 , passa a vigorar acrescida do seguinte art. $4^{\circ}-\mathrm{A}$ :

"Art. $4^{\circ}$-A Praticar o empregador ou seu preposto atos de dispensa direta ou indireta:

Pena: reclusão de 2 (dois) a 5 (cinco) anos."

Art. $5^{\circ}$ Os arts. $5^{\circ}, 6^{\circ}$ e $7^{\circ}$ da Lei $\mathrm{n}^{\circ} 7.716$, de 5 de janeiro de 1989 , passam a vigorar com a seguinte redação:

"Art. $5^{\circ}$ Impedir, recusar ou proibir o ingresso ou a permanência em qualquer ambiente ou estabelecimento público ou privado, aberto ao público:

Pena: reclusão de 1 (um) a 3 (três) anos.”( NR) 
"Art. $6^{\circ}$ Recusar, negar, impedir, preterir, prejudicar, retardar ou excluir, em qualquer sistema de seleção educacional, recrutamento ou promoção funcional ou profissional:

Pena - reclusão de 3 (três) a 5 (cinco) anos.

Parágrafo único. (Revogado).”(NR)

"Art. $7^{\circ}$ Sobretaxar, recusar, preterir ou impedir a hospedagem em hotéis, motéis, pensões ou similares:

Pena - reclusão de 3 (três) a 5 (cinco) anos.”(NR)

Art. $6^{\circ}$ A Lei ${ }^{\circ} 7.716$, de 5 de janeiro de 1989, passa a vigorar acrescida do seguinte art. $7^{\circ}-\mathrm{A}$ :

"Art. $7^{\circ}$-A Sobretaxar, recusar, preterir ou impedir a locação, a compra, a aquisição, o arrendamento ou o empréstimo de bens móveis ou imóveis de qualquer finalidade:

Pena: reclusão de 2 (dois) a 5 (cinco) anos."

Art. $7^{\circ}$ A Lei ${ }^{\circ} 7.716$, de 5 de janeiro de 1989, passa a vigorar acrescida dos seguintes art. $8^{\circ}-\mathrm{A}$ e $8^{\circ}-\mathrm{B}$ :

"Art. $8^{\circ}$-A Impedir ou restringir a expressão e a manifestação de afetividade em locais públicos ou privados abertos ao público, em virtude das características previstas no art. $1^{\circ}$ desta Lei:

Pena: reclusão de 2 (dois) a 5 (cinco) anos."

"Art. $8^{\circ}$-B Proibir a livre expressão e manifestação de afetividade do cidadão homossexual, bissexual ou transgênero, sendo estas expressões e manifestações permitidas aos demais cidadãos ou cidadãs:

Pena: reclusão de 2 (dois) a 5 (cinco) anos."

Art. $8^{\circ}$ Os arts. 16 e 20 da Lei $\mathrm{n}^{\circ} 7.716$, de 5 de janeiro de 1989, passam a vigorar com a seguinte redação:

"Art. 16. Constituem efeito da condenação:

I - a perda do cargo ou função pública, para o servidor público;

II - inabilitação para contratos com órgãos da administração pública direta, indireta ou fundacional;

III - proibição de acesso a créditos concedidos pelo poder público e suas instituições financeiras ou a programas de incentivo ao desenvolvimento por estes instituídos ou mantidos;

IV - vedação de isenções, remissões, anistias ou quaisquer benefícios de natureza tributária;

V - multa de até 10.000 (dez mil) UFIRs, podendo ser multiplicada em até $10(\mathrm{dez})$ vezes em caso de reincidência, levando-se em conta a capacidade financeira do infrator;

VI - suspensão do funcionamento dos estabelecimentos por prazo não superior a 3 (três) meses. 
$\S 1^{\circ}$ Os recursos provenientes das multas estabelecidas por esta Lei serão destinados para campanhas educativas contra a discriminação.

$\S 2^{\circ}$ Quando o ato ilícito for praticado por contratado, concessionário, permissionário da administração pública, além das responsabilidades individuais, será acrescida a pena de rescisão do instrumento contratual, do convênio ou da permissão.

$\S 3^{\circ}$ Em qualquer caso, o prazo de inabilitação será de 12 (doze) meses contados da data da aplicação da sanção.

$\S 4^{\circ}$ As informações cadastrais e as referências invocadas como justificadoras da discriminação serão sempre acessíveis a todos aqueles que se sujeitarem a processo seletivo, no que se refere à sua participação.”(NR)

"Art. 20. Praticar, induzir ou incitar a discriminação ou preconceito de raça, cor, etnia, religião, procedência nacional, gênero, sexo, orientação sexual e identidade de gênero:

$\S 5^{\circ} \mathrm{O}$ disposto neste artigo envolve a prática de qualquer tipo de ação violenta, constrangedora, intimidatória ou vexatória, de ordem moral, ética, filosófica ou psicológica."(NR)

Art. $9^{\circ}$ A Lei $\mathrm{n}^{\circ} 7.716$, de 5 de janeiro de 1989, passa a vigorar acrescida dos seguintes arts. 20-A e 20-B:

"Art. 20-A. A prática dos atos discriminatórios a que se refere esta Lei será apurada em processo administrativo e penal, que terá início mediante:

I - reclamação do ofendido ou ofendida;

II - ato ou ofício de autoridade competente;

III - comunicado de organizações não governamentais de defesa da cidadania e direitos humanos."

"Art. 20-B. A interpretação dos dispositivos desta Lei e de todos os instrumentos normativos de proteção dos direitos de igualdade, de oportunidade e de tratamento atenderá ao princípio da mais ampla proteção dos direitos humanos.

$\S 1^{\circ}$ Nesse intuito, serão observadas, além dos princípios e direitos previstos nesta Lei, todas as disposições decorrentes de tratados ou convenções internacionais das quais o Brasil seja signatário, da legislação interna e das disposições administrativas.

$\S 2^{\circ}$ Para fins de interpretação e aplicação desta Lei, serão observadas, sempre que mais benéficas em favor da luta antidiscriminatória, as diretrizes traçadas pelas Cortes 
Internacionais de Direitos Humanos, devidamente reconhecidas pelo Brasil."

Art. 10. $\mathrm{O} \S 3^{\circ}$ do art. 140 do Decreto-Lei $\mathrm{n}^{\circ} 2.848$, de 7 de dezembro de 1940 - Código Penal, passa a vigorar com a seguinte redação:

"Art. 140.

$\S 3^{\circ}$ Se a injúria consiste na utilização de elementos referentes à raça, cor, etnia, religião, procedência nacional, gênero, sexo, orientação sexual e identidade de gênero, ou a condição de pessoa idosa ou portadora de deficiência:

Pena: reclusão de 1 (um) a 3 (três) anos e multa."(NR)

Art. 11. O art. $5^{\circ}$ da Consolidação das Leis do Trabalho - CLT, aprovada pelo Decreto-Lei ${ }^{\circ} 5.452$, de $1^{\circ}$ de maio de 1943, passa a vigorar acrescido do seguinte parágrafo único:

"Art. $5^{\circ}$

Parágrafo único. Fica proibida a adoção de qualquer prática discriminatória e limitativa para efeito de acesso a relação de emprego, ou sua manutenção, por motivo de sexo, orientação sexual e identidade de gênero, origem, raça, cor, estado civil, situação familiar ou idade, ressalvadas, neste caso, as hipóteses de proteção ao menor previstas no inciso XXXIII do caput do art. $7^{\circ}$ da Constituição Federal.”(NR)

Art. 12. Esta Lei entra em vigor na data de sua publicação.

Sala das Sessões, em 23 de novembro de 2006.

Relator 